\title{
The Impact of Climate on Southeast Asia, circa 950-1820: New Findings
}

\author{
VICTOR LIEBERMAN
}

\author{
University of Michigan \\ Email:eurasia@umich.edu
}

BRENDAN BUCKLEY

Lamont-Doherty Earth Observatory, Columbia University
Email:bmb@ldeo.columbia.edu

\begin{abstract}
The recent discovery of continuous tree-ring series starting as early as $1030 \mathrm{CE}$ has for the first time made possible the reconstruction of historical climates for much of mainland Southeast Asia. Perhaps the most dramatic finding is that wide cyclic fluctuations in the reach and volume of monsoon rains contributed substantially to both the genesis and the collapse of the charter civilizations of Angkor, Pagan, and Dai Viet. From circa 1450-1820 climate continued to influence political and economic development, but its impact appears to have diminished both because the amplitude of hydrological fluctuations decreased markedly, and because new sources of power rendered early modern Southeast Asian states more resilient. A pioneering collaborative effort by a historian and a paleoclimatologist, this paper promises three benefits: It can help to solve a variety of local historiographic puzzles, it can facilitate construction of a synchronized historical narrative for mainland Southeast Asia as a whole, and it can aid comparisons between mainland Southeast Asia and other sectors of Eurasia.
\end{abstract}

\section{Introduction}

At first glance, the quantitative nature of paleoclimatology promises historians of the pre-modern era objectivity in a field where hard data can be frustratingly scarce. For those interested in global comparisons, climate also offers a link between distant regions. But on closer inspection, ambiguous climate records can render objectivity a 
chimera, and even with full data sets, isolating the impact of climate from social factors is more than daunting.

Both these attractions and pitfalls are obvious in the historiography of pre-colonial Southeast Asia, where large and hopeful claims have been made for climatic influence but where reliable information has been quite limited. Anthony Reid - a pioneer in this as in other fields of Southeast Asian history-was the first to invoke climate as an explanatory region-wide variable. In his justly acclaimed Southeast Asia in the Age of Commerce 1450-I680, he argued that during the mid and late 1600 Southeast Asia suffered a climatic downturn typical of the nadir of the Little Ice Age. ${ }^{1}$ Hemispheric cooling yielded weaker monsoons, droughts, and famines, which joined Dutch competition to shrivel indigenes' once robust engagement with global trade, along with indigenous political fortunes. ${ }^{2}$ More recently Victor Lieberman, focusing on mainland Southeast Asia, suggested that higher rainfall in three periods-most notably the Medieval Climate Anomaly circa

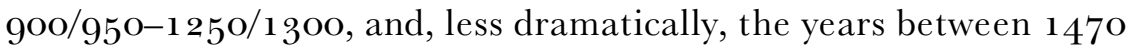
and 1590 , and 1710 and $1810-$-spurred agricultural and population growth. By contrast, the late thirteenth to mid fifteenth centuries and (as Reid argued) much of the seventeenth century tended to be drier and less agriculturally propitious. ${ }^{3}$

Yet, as both historians readily conceded, a dearth of local paleoclimatic records often rendered the argument moot. Apart from a $4^{10-y e a r}$ Javanese teak tree-ring series on which Reid drew, ${ }^{4}$ he

${ }^{1}$ Anthony Reid, Southeast Asia in the Age of Commerce, I450- I 680. Volume 2. Expansion and Crisis (New Haven: Yale University Press, 1993), Chapter 5, especially pp. 291298. Reid adumbrated these ideas in 'The Seventeenth-Century Crisis in Southeast Asia', Modern Asian Studies 24 (1990): 639-659, especially pp. 654-656.

${ }^{2}$ Using Dutch East India Company records to test Reid's thesis for the islands, Peter Boomgaard agreed that the seventeenth century saw serious climatically-related disruptions, but questioned whether they were much worse than earlier or later periods. Boomgaard, 'Crisis Mortality in Seventeenth-Century Indonesia', in Ts'uijung Liu et al., eds, Asian Population History (Oxford: Oxford University Press, 2001), 191-220, especially p. 195 .

${ }^{3}$ Victor Lieberman, Strange Parallels: Southeast Asia in Global Context, c. 80o-I 830. Volume I. Integration on the Mainland (Cambridge: Cambridge University Press, 2003) [hereafter $S P \mathrm{I}$ ], pp. 49, 78, 101-112, 121, 142-143, 156-157, 174, 176, 224-226, 239-240, 253, 265, 276, 295, 306, 363-364, 370-371, 385, 396, 420, 438-439, 459; and Volume 2. Mainland Mirrors: Europe, Japan, China, South Asia, and the Islands (Cambridge: Cambridge University Press, 2oog) [hereafter SP II], pp. 33, 79-84, $146,162,240-243,27^{6}, 330,4^{1} 7-418,79^{2}$.

${ }^{4}$ See Reid, Age of Commerce, pp. 291-296; tabulation of H. P. Berlage's findings in H. H. Lamb, Climate: Present, Past and Future. Volume 2. (London: Methuen, 1977), pp. 6o3-6o6; and discussion of Berlage's data in J. O. Murphy and P. H. Whetton, 
and Lieberman were obliged to rely on archaeology and somewhat impressionistic notices of drought, floods, famine, and population shifts in indigenous chronicles and European accounts. This material they supplemented with hydrological records from pre-1820 South China, South Asia, and the Pacific, whose climates are linked to those of Southeast Asia in complex ways. But from Southeast Asia itself, especially the mainland, direct scientific data remained exiguous.

In the eight years since Lieberman's early work appeared, research on mainland climate has advanced substantially. Whereas it was long believed that in continental Southeast Asia, as in much of the tropics, inadequate seasonality inhibited annual tree-rings, Brendan Buckley and his colleagues have found teak trees in northwest Thailand with well-defined rings produced by locally distinct wet and dry seasons

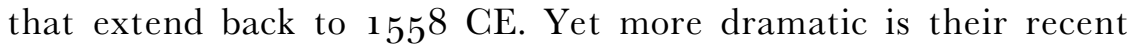
discovery in the southern and northern highlands of Vietnam of rare cypress trees (Fokienia hodginsii) whose rings show remarkable fidelity to instrumental records and, in the case of the southern cypresses, span 979 years from 1030 to 2008 CE. Because the annual growth of teak and cypress correlates strongly with soil moisture, tree-rings provide an accurate proxy of rainfall as determined by the strength and duration of the summer monsoon. ${ }^{5}$ In turn, rainfall was by far the single most important non-anthropogenic determinant of rice yields and acreage, not only in rain-fed districts but also in irrigated and flood-dependent terrains. ${ }^{6}$

The Thai and Vietnamese sites are separated from one another by $600-1300 \mathrm{~km}$, but because their growth sequences correlate

'A Re-Analysis of a Tree-Ring Chronology from Java', Dendrochronology. Proceedings, B92 (1989): 241-257; J. G. Palmer and J. O. Murphy, 'An Extended Tree Ring Chronology (Teak) from Java', Proceedings. Koninklijke Nederlandse Akademie van Wetenschappen 96 (1993): 27-41.

5 See Brendan Buckley et al., 'Dendrochronological Investigations in Thailand', IAWA Journal 16 (1995): 393-409; Brendan Buckley et al., 'Decadal Scale Droughts over Northwestern Thailand Over the Past $44^{8}$ Years', Climate Dynamics 29 (2007): 63-71; Masaki Sano, Brendan Buckley, and Tatsuo Sweda, 'Tree-Ring Based Hydroclimate Reconstruction over Northern Vietnam from Fokienia Hodginsii: Eighteenth-Century Mega-drought and Tropical Pacific Influence', Climate Dynamics 33 (2009): 331-340; Brendan Buckley et al., 'Climate as a Contributing Factor in the Demise of Angkor, Cambodia', Proceedings of the National Academy of Sciences [henceforth $P N A S] 107$ (2010): 6748-6752.

${ }^{6}$ Irrigation generally depended either on streams or tanks, both sensitive over the medium and long term to changes in rainfall. See discussion and sources from SP I in n. 3 supra, plus I. Amien et al., 'Effects of Interannual Climate Variability and Climate Change on Rice Yield in Java, Indonesia', Water, Air, and Soil Pollution 2 (1996): 29-39. 
reasonably well, we may assume that the rainfall patterns they record characterized a good deal of the central and eastern mainland. Insofar as the Thai teak site of Mae Hong Son lies on the Burma border some $220 \mathrm{~km}$ from the Irrawaddy basin, one is tempted to assume substantial concordance with central Burmese patterns as well. Confidence in Thai and Vietnamese records is further strengthened by broad concordance with multi-proxy monsoon reconstructions across East and South Asia. ${ }^{7}$

These discoveries promise to modify substantially the historiography of mainland Southeast Asia during 900 years, both by validating and challenging earlier reconstructions. On the one hand, they provide empirical support for Lieberman's hypothesis that stronger monsoons typical of the Medieval Climate Anomaly contributed to the early success of the mainland 'charter states' of Pagan in Upper Burma, Angkor in Cambodia, and Dai Viet in northern Vietnam, and that after circa 1300 the onset of the desiccative Little Ice Age helped to undermine those same polities. In fact, the transition from the Medieval Climate Anomaly to the Little Ice Age is thought to have initiated a southward shift, lasting over 5 oo years, in the position of the Inter-tropical Convergence Zone, which is where winds originating in the northern and southern hemispheres come together. This shift was probably responsible for the prolonged and lethal Angkor Droughts that Buckley has documented during the 1300 and 1400 , and for the associated turmoil across the mainland. ${ }^{8}$

On the other hand, by complicating our understanding of the

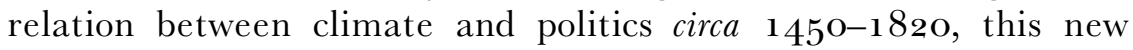
research demands a more nuanced narrative than either Lieberman

${ }^{7}$ Compare sources in n. 5 supra with Edward Cook et al., 'Asian Monsoon Failure and Megadrought During the Last Millennium', Science 328 (2010): 486-89; Rosanne D'Arrigo et al., 'On the Variability of ENSO Over the Past Six Centuries', Geophysical Research Letters [hereafter GRL] 32 (2005): L 0371 1; Rosanne D'Arrigo, Rob Wilson, and Jinbao Li, 'Increased Eurasian-Tropical Temperature Amplitude Difference in Recent Centuries: Implications for the Asian Monsoon', GRL 33 (2006): L 1227o6; Michael Mann et al., 'Volcanic and Solar Forcing of the Tropical Pacific Over the Past 1000 Years', Journal of Climate 18 (2005): 447-454; Gerald Meehl and Aixue $\mathrm{Hu}$, 'Megadroughts in the Indian Monson Region and Southwest North America and a Mechanism for the Associated Multidecadal Pacific Sea Surface Temperature Anomalies', Journal of Climate 19 (2006): 1605-1623.

${ }^{8}$ On the definition of 'charter states' and the impact of climate on charter state fortunes, see n. 3 supra; Victor Lieberman, 'Charter State Collapse in Southeast Asia c. $125^{0}-1400$, as a Problem in Regional and World History', The American Historical Review 116 (2011): 937-963; Buckley, 'Climate as a Contributing Factor;' and discussion infra. 
or Reid has yet offered. It supports their basic intuition that climate helped to govern agrarian rhythms. But it suggests that such influence waned after $145^{\circ}$, both because the scale of monsoon fluctuations diminished notably, and because more diverse and independent sources of power rendered Southeast Asian states, and to some extent the wider societies, less vulnerable to climatic pressures. In short, this paper urges greater attention to climate, whilst avoiding climatic determinism. Insofar as this research parallels recent work in European, Chinese, and global paleoclimatology, and provides independent corroboration for Indian and South Chinese patterns, it may also be of interest to non-Southeast Asianists. ${ }^{9}$

After sketching monsoon dynamics, we weigh their economic and political implications for mainland Southeast Asia during four periods, each of which was reasonably coherent politically and, to some extent, culturally: (1) charter florescence, circa 950-1250/1300; (2) charter

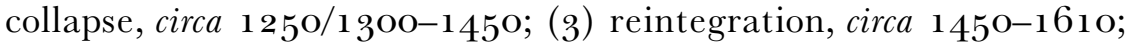
(4) the high pre-colonial era, circa 1610-1820.

\section{Monsoon dynamics}

Spanning decades or even centuries, extended periods of northern hemispheric warming tend to enhance the strength of summer monsoons by increasing water vapour in the tropical atmosphere and by magnifying the land-sea thermal contrast that pulls moisture-laden

${ }^{9}$ On climatic correlations between Southeast Asia and other sectors of Eurasia, see Lieberman, 'Charter State Collapse;' SP II, Chapterss. 1-6; David Zhang et al., 'The Causality Analysis of Climate Change and Large-Scale Human Crisis', PNAS Early Edition, available online at URL: http://www.pnas.org/search, type in the 'doi' box: 10,1073/pnas.1 104268108 [accessed 1 February 2012]; Robert Marks, Tigers, Rice, Silk, and Silt (Cambridge: Cambridge University Press, 1998); Pingzhong Zhang et al., 'A Test of Climate, Sun, and Culture Relationships from an 1810 -Year Chinese Cave Record', Science 322 (2008): 940-942; Zhang De'er et al., 'On Linking Climate to Chinese Dynastic Change', Chinese Science Bulletin 55 (2010): 77-83; Xunming Wang et al., 'Climate, Desertification, and the Rise and Collapse of China's Historical Dynasties', Human Ecology 38 (2010): 157-172; Timothy Brook, The Troubled Empire (Cambridge, Massachusetts: Harvard University Press, 2010); David Zhang et al., 'Global Climate Change, War, and Population Decline in Recent Human History', PNAS 104 (2007): 19214-19219; Geoffrey Parker, 'Crisis and Catastrophe: The Global Crisis of the Seventeenth Century Reconsidered', The American Historical Review 113 (2008): 1053-1079; William Atwell, 'Time, Money, and the Weather', Journal of Asian Studies [henceforth $J A S$ ] 61 (2002): 83-1 14; idem, 'Volcanism and Short-Term Climatic Change in East Asian and World History, c. 1200-1699', Journal of World History 12 (2001): 29-98. 
summer winds into Asia from the relatively cool Indian and Pacific Oceans and the South China Sea. At the same time hemispheric warming drags the Inter-tropical Convergence Zone northwards, thus allowing monsoons to penetrate farther inland. In reverse fashion, as just indicated, prolonged cooling reduces the thermal contrast, shifts the Zone southwards, and thus compresses the volume, reach, and duration of summer rains. ${ }^{10}$

Before the post- $185^{\circ}$ intensification of anthropogenic change, three principal forcing mechanisms are thought to have governed longterm modifications in hemispheric climate, namely, variations in solar activity, in volcanism, and in ocean currents.

Some studies claim that, prior to circa $185^{\circ}$, fluctuations in solar radiation accounted for up to 70 per cent of the earth's temperature shifts. As determined by ice cores, tree-rings, lake sediments, and sunspot measurements, solar radiation was particularly strong from the tenth to late thirteenth centuries, that is, during the Medieval Climate Anomaly. It was especially weak during the Wolf Minimum of radiation (circa 1280-1340), the Sporer Minimum (circa 1400-1515 or circa 1450-1535), the Maunder Minimum (circa 1645-1715), and the Dalton Minimum (circa 1795-1825), all of which fell within the Little Ice Age. ${ }^{11}$

By injecting into the atmosphere sulfate aerosols that deflect the sun's radiation back into space, volcanism can reinforce the cooling impact of reduced radiation and can moderate the warming effects of radiation increases. Between 1200 and 1699 William Atwell calculated that volcanism helped to lower hemispheric temperatures in at least 160 years, with especially pronounced impacts from $1225^{-}$ $1233,125^{6-1262}, 1444^{-1} 4^{6} 5,15^{8} 4^{-16} 10$, and $1636-1644$. On the other hand, some recent work points to stronger monsoons in the year

${ }^{10}$ Charles A. Fisher, South-East Asia: A Social, Economic and Political Geography (London: Methuen, 1964), 28-42; D'Arrigo, Wilson, and Li, 'Increased EurasianTropical Temperature Amplitude'; Peter Boomgaard, Southeast Asia: An Environmental History (Santa Barbara: ABC-Clio, 2007), ch. 4; Richard Allen and Brian Soden, 'Atmospheric Warming and the Amplification of Precipitation Extremes', Science Express, 7 Aug., 2009, 1-7; and especially Ashish Sinha et al., 'A Global Context for Megadroughts in Monsoon Asia During the Past Millennium', Quarternary Science Reviewes 30 (2010): 1-16.

${ }^{11}$ On solar radiation, Douglas Hoyt and Kenneth Schatten, The Role of the Sun in Climate Change (Oxford: Oxford University Press, 1997), chs. 10, 1 1; Mike Lockwood, 'Solar Change and Climate', Proceedings of the Royal Society. A. 466 (2010): 303-329. 
immediately following high aerosol-producing tropical eruptions, so volcanism's net impact remains unclear. ${ }^{12}$

Finally, decades to centuries-long oscillations in the heat economy of ocean currents profoundly influence Asian temperatures and precipitation. The oceanic system most relevant to Southeast Asia is the El Niño Southern Oscillation, which refers to the alternation between phases of cool and warm sea surface temperatures in the east and central tropical Pacific. The phase of cool temperatures is known as La Niña, and the warm phase as El Niño. ${ }^{13}$ By moving water and air warmed by the sun from the east and central to the western Pacific and the eastern Indian Ocean, La Niña winds and currents tend to enhance Southeast Asian, South Asian, and South Chinese monsoons. Conversely, by interrupting this circulation, El Niño events tend to induce drought in Southeast Asia, India, and South China. Coral, speleothem, sediment, and dendrological data suggest that during much of the monsoon-rich Medieval Climate Anomaly, La Niña was a persistent base-like state in the Indo-Pacific tropics. ${ }^{14}$ It yielded to more frequent El Niño episodes for much of the fourteenth and fifteenth centuries and during certain periods in the seventeenth, eighteenth, and early nineteenth centuries. ${ }^{15}$

${ }^{12} \mathrm{~K}$. J. Anchukaitis et al., 'Influence of Volcanic Eruptions on the Climate of the Asian Monsoon Region', GRL 37 (2010), L22703. However, this enhancing effect is not observed with extra-tropical eruptions. See Atwell, 'Volcanism and Short-Term Climatic Change'; Mann, 'Volcanic and Solar Forcing'; R. S. Bradley and P. D. Jones, 'Records of Explosive Volcanic Eruptions Over the Last $5^{\text {oo }}$ Years', in Bradley and Jones, Climate Since A.D. I5oo (London: Routledge, 1995), pp. 6o6-622.

${ }^{13}$ Some scientists argue that increased solar radiation and/or reduced volcanism generate or prolong La Niña phases, but others believe that the ENSO arises from dynamics internal to the oceanic system itself. See discussion in Michael Man et al, 'Global Signatures and Dynamical Origins of the Little Ice Age and Medieval Climate Anomaly', Science 326 (2009): 1256-1 26o; Valerie Trouet et al., 'Persistent Positive North Atlantic Oscillation Mode Dominated the Medieval Climate Anomaly', Science 324 (2009): 78-80; Buckley, 'Climate as a Contributing Factor', 6751; Kim Cobb et al., 'El Niño/Southern Oscillation and Tropical Pacific Climate During the Last Millennium', Nature 424 (2003): 271-276.

${ }^{14}$ See, e.g., Mann, 'Global Signatures.' On the Medieval Climate Anomaly as a global and Asian phenomenon, see n. 12 supra; Meehl and Hu', Megadroughts'; Cook, 'Asian Monsoon Failure'; Willie Soon, Sallie Baliunas et al., 'Reconstructing Climatic and Environmental Changes of the Past 1000 Years: A Reappraisal', Energy and Environment 14 (2003): 233-296; Zhang, 'Global Climate Change'; Timothy Osborne and Keith Briffa, 'The Spatial Extent of 2oth-Century Warmth in the Context of the Past 1200 Years', Science 311 (2006): 841-844; Zhang, 'Test of Climate.'

${ }^{15}$ Particularly strong El Niño events in South Asia and/or mainland Southeast Asia are recorded in $1594^{-1} 597,1629^{-1} 64_{1}^{1}, 1685^{-1688,1789-1796}$, and $175^{6-1} 7_{68}$. See Richard Grove and John Chappell, eds, El Niño: History and Crisis (Cambridge: 
Note that, despite broad concordance across monsoon Asia, topographical idiosyncrasies and local shifts in wind circulation could produce significant rainfall discrepancies, at least in the short term, between different sectors of mainland Southeast Asia as well as between parts of India, South China, and Southeast Asia. ${ }^{16}$

The following graphs record the combined impact on mainland hydroclimate of solar radiation, volcanism, and the El Niño Southern Oscillation as recorded in the above studies of southern and northern Vietnamese cypresses-captured in Figures 1 and 2, respectivelyand of Thai teak in Figure 3. Rainfall values in Figures 1 and 2 are expressed in terms of the Palmer Drought Severity Index (PDSI), while Figure 3 records tree-ring widths as a proxy for rainfall. ${ }^{17}$ Figure 4 offers corroborating data based on speleothem calcite, i.e. stalagmite, records from Dandak Cave in east central India's core monsoon area. ${ }^{18}$ Figure 5 provides a composite time series for El Niño events over 1400 years, showing a marked reduction in such events during the Medieval Climate Anomaly.

\section{The charter era on the mainland, circa $95^{0-1250 / 1300}$}

How, then, did climate influence Southeast Asian political and economic development? Its earliest documented and arguably most

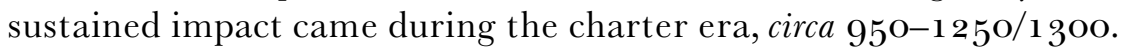

Pagan, Angkor, and Dai Viet were all 'charter states' in the sense that each realm, as the earliest extensive indigenous polity in its

White Horse Press, 2000), Chapter 1; Cook, 'Asian Monsoon Failure'; Mann, 'Volcanic and Solar Forcing'; W. H. Quinn and V. T. Neal, 'The Historical Record of El Niño Events', in Bradley and Jones, Climate Since A.D. I 5oo, pp. 623-648; Luc Ortlieb, 'The Documented Historical Record of El Niño Events in Peru', in Henry Diaz and Vera Markgraf, eds, El Niño and the Southern Oscillation (Cambridge: Cambridge University Press, 2000), 207-295; Vera Markgraf and Henry Diaz, 'The Past ENSO Record: A Synthesis', in ibid., pp. $465-488$.

${ }^{16}$ See, e.g., Sano, 'Tree-Ring Based Hydroclimate Reconstruction', and Figures $1-4$ in this paper.

${ }^{17}$ On the PDSI, see Buckley, 'Climate as a Contributing Factor', 6748, and on tree-ring widths, Buckley, 'Decadal Scale Droughts.'. The southern Vietnamese site is Bidoup Nui Ba National Park, the northern Vietnamese site is Mu Cang Chai, while the Thai site is Mae Hong Son. See n. 5 supra.

${ }^{18}$ Sinha, 'A Global Context for Megadroughts'; Ashish Sinha et al., 'A goo-Year (6oo to 15 oo A.D.) Record of the Indian Summer Monsoon Precipitation from the Core Monsoon Zone of India', GRL 34 (2007): L 16707. See also, corroborating records from Wanxiang Cave in North China in Zhang, 'Test of Climate'. 


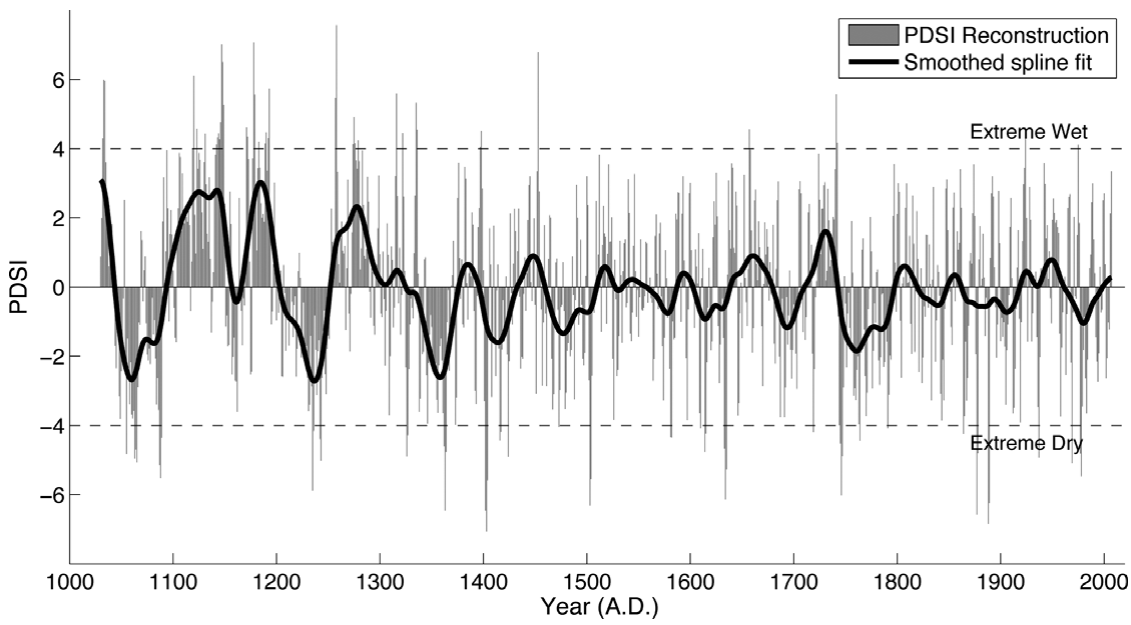

Figure 1. Precipitation in southern Vietnam, measured according to the Palmer Drought Severity Index (PDSI), as reconstructed from tree-ring-widths of cypress trees (Fokienia hodginsii) growing in the highlands of Vietnam's Bidoup Nui Ba National Park. The higher the PDSI reading, the higher the annual rainfall. Although the sample size prior to $125^{\circ}$ is smaller than after $125^{\circ}$, the overall trend and multidecadal structure of the reconstruction imply far wetter than average conditions throughout key portions of the Medieval Warm Period, consistent with La Niña-like base state conditions. ${ }^{19}$

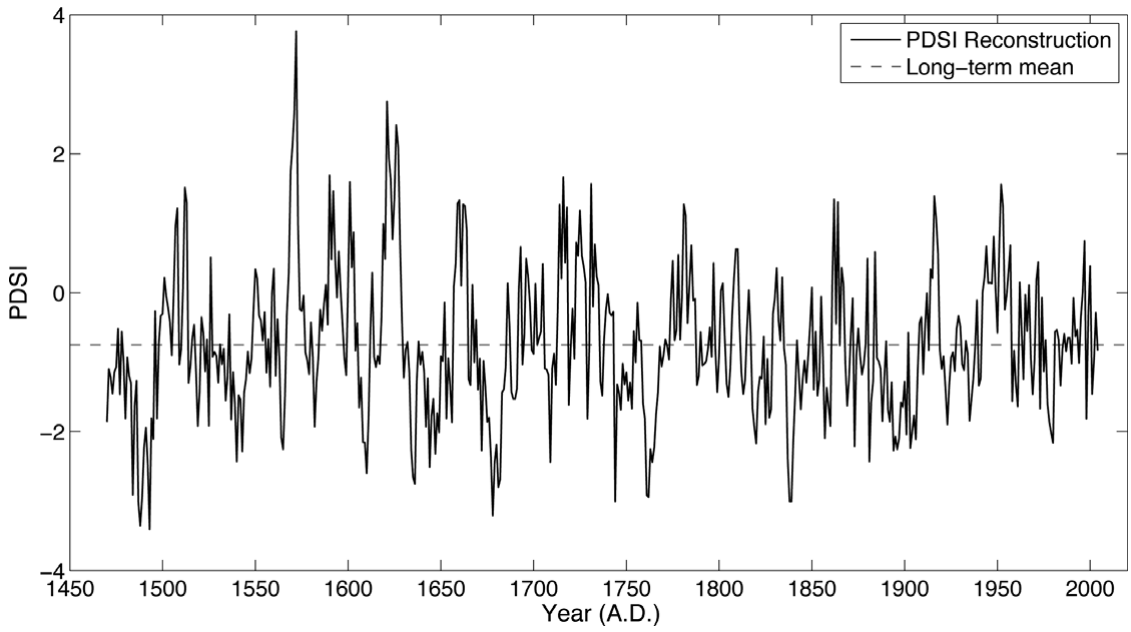

Figure 2. Precipitation in northern Vietnam, measured according to the Palmer Drought Severity Index (PDSI), as reconstructed from tree-ring-widths of cypress trees (Fokienia hodginsii) growing in the Mu Cang Chai area of Vietnam. The higher the PDSI reading, the higher the annual rainfall. ${ }^{20}$

19 Source: Buckley, 'Climate as a Contributing Factor', Fig. S3.

${ }^{20}$ Source: Sano, 'Tree-Ring-Based Hydroclimate Reconstruction, Fig. 5b. 


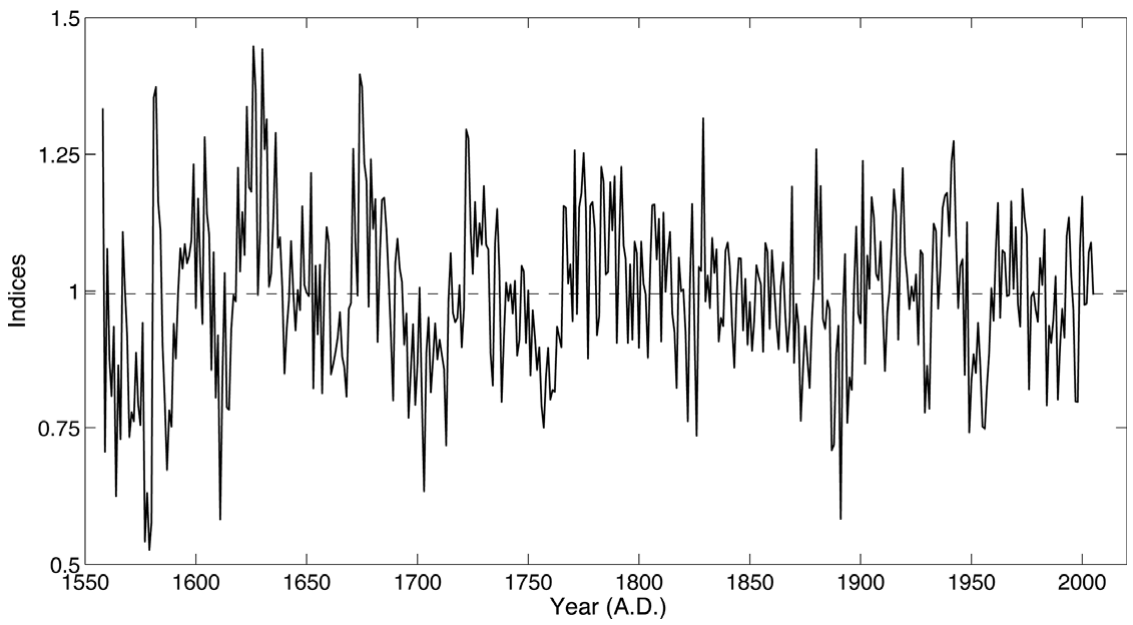

Figure 3. Teak tree-ring widths, as a proxy for rainfall, from Mae Hong Son, Thailand. The wider the tree-ring, the higher the annual rainfall. ${ }^{21}$

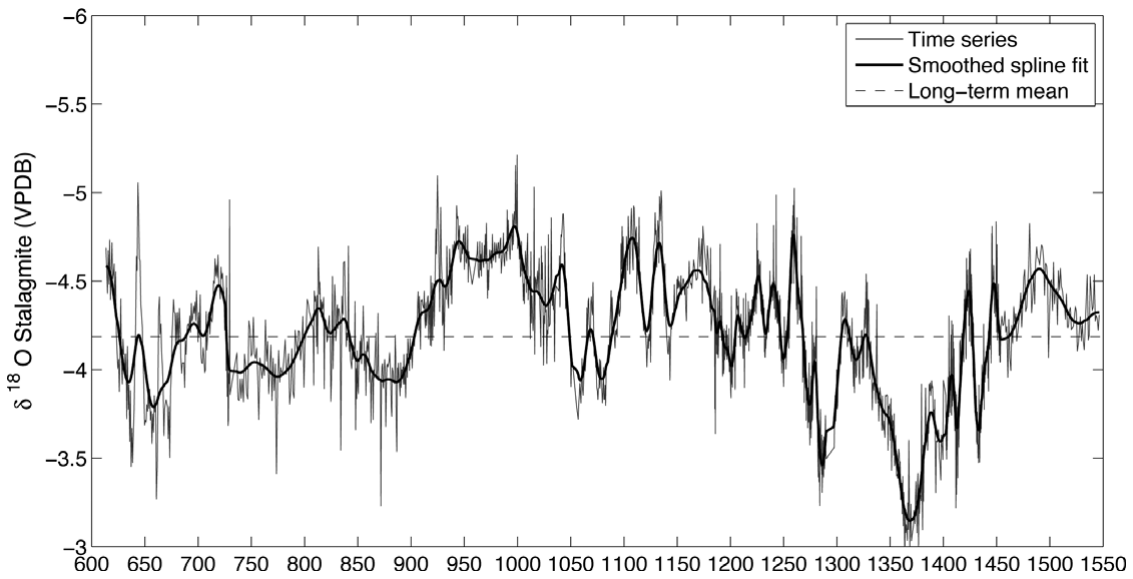

Figure 4. Stalagmite records, as a proxy for rainfall, from Dandak Cave in east central India. The left vertical axis shows the isotopic weight of precipitating rainwater, which correlates positively to precipitation. The right vertical axis shows precipitation as a percentage deviation from the twentieth-century mean, with droughts indicated by negative values. ${ }^{22}$

area, provided a political, territorial, and high cultural charter for subsequent generations. All three flourished from the tenth to the

${ }^{21}$ Source: Buckley, 'Decadal Scale Droughts, Fig. 2A.

22 Source: Sinha, 'A Global Context for Megadroughts, Fig. 2 (top sector). 


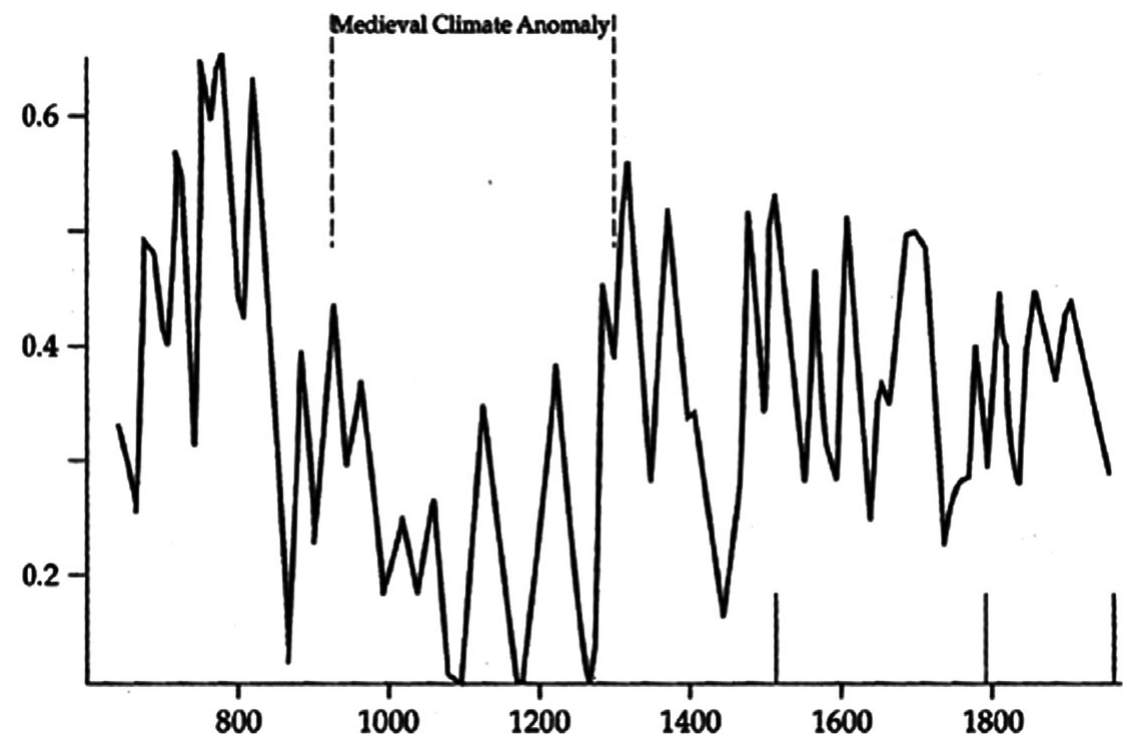

Figure 5. Composite time series for recurrence of El Niño events since 622 CE. Vertical axis represents events per year. ${ }^{23}$

thirteenth centuries-during the Medieval Climate Anomaly-and all three collapsed between 1280 and 1400 , during the transition into the Little Ice Age.

The genesis of these polities was not tightly coordinated. As early as 802 Jayavarman II united (albeit temporarily) the Khmer lands, and by the early goos Khmer civilization, centred at Angkor, boasted its defining features, including monumental temple construction and elaborate hydraulic works. ${ }^{24}$ By contrast, although Upper Burma also supported irrigation and urban structures of some antiquity, not until

23 Source: SPI, 110, Fig. 2.3, in turn based on Roger Y. Anderson, 'Long-Term Changes in the Frequency of Occurrence of El Niño Events', in Henry Diaz and Vera Markgraf, eds, El Niño: Historical and Paleoclimatic Aspects of the Southern Oscillation (Cambridge, 1992), Fig. 9.1; Simon Haberle, 'Vegetation Response to Climatic Variability', in Grove and Chappell, El Niño, Fig. 1.

${ }^{24}$ Michael Vickery, Society, Economics, and Politics in Pre-Angkor Cambodia (Tokyo: Centre for East Asian Cultural Studies, 1998); Ian Mabbett and David Chandler, The Khmers (Oxford: Blackwell, 1995), Chapters 6-8; Michael Coe, Angkor and the Khmer Civilization (New York: Thames and Hudson, 2003), Chapters 5-6; David Chandler, $A$ History of Cambodia ( $2^{\text {nd }}$ ed., Boulder, Colorado: Westview Press, 1992), Chapters 2-3; Charles Higham, The Civilization of Angkor (London: Widenfeld and Nicolson, 2001); Charles Ortloff, Water Engineering in the Ancient World (Oxford: Oxford University Press, 2009), pp. 358-376; Dan Penny et al., 'Vegetation and Land-Use at Angkor, Cambodia', Antiquity 8o (2006): 599-614. 
the eleventh century did Pagan transform its system of autonomous city-states into a centralized kingdom, thus recalling Jayavarman II's ambition some 200 years earlier. ${ }^{25}$ A Chinese province for most of the first millennium and independent only from 939, the northern Vietnamese area that would become known as Dai Viet also failed to support a stable indigenous polity until the early eleventh century. ${ }^{26}$

Given these staggered starting points, remarkable indeed was the subsequent convergence of the charter states. Beginning with Rajendravarman (r. 944-968), whose reign is said to have constituted 'one of the major discontinuities' of Khmer history, ${ }^{27}$ and continuing through to the early 1200 , several interlinked developments at Angkor point to a novel phase. Notwithstanding Jayavarman II's early aspirations, not until the tenth century did the notion of a unified Khmer polity gain stable expression. After 890 , and more especially 1000, hydraulic and religious construction assumed an unprecedented scale, with the vast Eastern, Western, and Northern Barays (reservoirs) supplementing or replacing earlier water storage facilities and with twelfth-century Angkor Wat becoming the largest religious monument of all time. ${ }^{28}$ Angkor's core population, perhaps $75^{\text {o,ooo } \text { at its peak }}$ around 1200 , also came to constitute what has been termed the 'largest low density urban complex in the preindustrial world'. ${ }^{29}$

${ }^{25}$ On Upper Burma to circa 11 100, Bob Hudson, 'The Origins of Bagan [sic]' (University of Sydney Ph.D. dissertation, 2004); Michael Aung-Thwin, Pagan: The Origins of Modern Burma (Honolulu: University of Hawaii Press, 1985), Chapter 1; Gordon Luce, Old Burma - Early Pagan, 3 vols. (Locust Valley, New York: J. J. Augustin Publishers, 1969-1970), I, Chapers 1-3; idem, Phases of Pre-Pagan Burma, 2 vols. (Oxford: Oxford University Press, 1985); Janice Stargardt, The Pyu of Ancient Burma (Cambridge: PACSEA, 1990).

${ }^{26}$ Keith Taylor, The Birth of Vietnam (Berkeley: University of California Press, 1983); idem, 'The "Twelve Lords" in Tenth-Century Vietnam', Journal of Southeast Asian Studies [hereafter JSEAS] 14 (1983): 46-62; Jennifer Holmgren, Chinese Colonisation of Northern Vietnam (Canberra: Australian National University, 1980); SP, I, $35^{2-363}$

${ }_{27}$ Mabbett and Chandler, Khmers, pp. 100, 165, 167, 169 .

${ }^{28}$ Charles Higham, The Archaeology of Mainland Southeast Asia (Cambridge: Cambridge University Press, 1989), p. 332; Mabbett and Chandler, Khmers, pp. 10o102, 149-150; Coe, Angkor, pp. $145^{-1} 4^{8}$.

${ }_{29}$ This characterization appears at Greater Angkor Project, 'Redefining Angkor: Structure and Environment in the Largest Low Density Urban Complex of the PreIndustrial World', Udaya 4 (2003): 107-125, citing a figure of $75^{\circ}$,ooo people within 1000-1500 square km around Angkor; and Damian Evans et al., 'A Comprehensive Archaeological Map of the World's Largest Preindustrial Settlement at Angkor, Cambodia', PNAS 104 (4 September 2007): 14277-14282. I have relied too on Roland Fletcher, personal communication, 13 January 2011. 
Khmer frontier colonization rolled north and west of the Great Lake heartland, and imperial authority spread over much of modern Thailand, Laos, and south Vietnam. ${ }^{30}$

In this same period (950-1250), Pagan exhibited a comparable leap in organizational complexity. The Burmans' earliest agrarian projects focused on rice irrigation in the Kyaukse basin, northeast of Pagan, and in Minbu, to the south. After these 'hubs' (hkayaings) had been developed, with population pressing on available resources, in the twelfth century Burmans moved into frontier regions (taiks) west of the Irrawaddy. Insofar as Buddhist temple-monasteries, like their Khmer counterparts, helped to spearhead reclamation, temple endowments and cultivation moved more or less in tandem. Both phenomena grew slowly into the late eleventh century, accelerated with the opening of taik lands in the twelfth century - the same century as gave birth to Angkor Wat-and continued at elevated, if diminished, levels to about 1300. Together, hkayaing intensification and taik extension reflected and permitted substantial population growth. In turn rising aggregate and possibly per capita wealth encouraged commercial exchange and political integration within the Upper Burma core, and military expansion north to Bhamo, west into Arakan, and south into Lower Burma. ${ }^{31}$

In what is now northern Vietnam, village records and family genealogies point to intensified movement after the tenth century from hilly areas of the Red River basin north and west of the capital into deltaic and coastal regions to the south and east. Taming the delta through polders and dikes was more taxing than cultivating the foothills, but potentially more rewarding insofar as more abundant water and more fertile soils facilitated multiple cropping. Between 1000 and 1300, and especially during the thirteenth century, the polder network expanded; new or extended dikes rechanneled the Red, Thai Binh, Ma, and Chu Rivers, whilst coastal barriers to

${ }^{30}$ Mabbett and Chandler, Khmers, Chapters 8-15, especially pp. 102-106, 171, 205, 262-263; Coe, Angkor, Chapters 5-7; Chandler, History, Chapters 3-4; Ortloff, Water Engineering; Roland Fletcher et al., 'The Development of the Water Management System of Angkor: A Provisional Model', Indo-Pacific Prehistory Association Bulletin 28 (2008): 57-66; Hubert de Mestier du Bourg, 'Le premiere moitie du XI siecle au Cambodge', Journal Asiatique $25^{8}$ (1970): 281-314, especially p. 308.

${ }^{31}$ Hudson, 'Origins of Bagan', p. 262 and Chapters 7, 8; Luce, Old Burma, I, 2938; U Maung Maung Tin, Myit-tha taze-ywa kwin-zin-lei-la chet-hmat-zu (Mandalay: Sa-pei bi-man htok, 200o); Aung-Thwin, Pagan, pp. 101-102, 186-192; manuscript version of Bob Hudson, Nyein Lwin, and Win Maung, 'The Origins of Bagan', Asian Perspectives 40 (2001), Fig. 1. 
tides and typhoons facilitated reclamation of extensive silt basins. Accordingly, the population in northern Vietnam grew from an estimated $1,600,000$ in 1000 to $3,000,000$ in $1300 .^{32}$

In summation, if political and institutional development at Angkor preceded that at Pagan and Dai Viet and if (on present evidence) the Vietnamese economy in the late thirteenth century showed somewhat greater vitality than its Khmer or Upper Burmese counterparts, for most of the period between $95^{\circ}$ and 1300 all three realms saw a dramatic increase in cultivation and population and an elaboration of imperial institutions.

Idiosyncratic local factors independent of climate surely influenced the timing of these expansions. In the Irrawaddy basin, for example, if we accept that ethnic Burmans entered in force only in the mid 8oos, ${ }^{33}$ and if we credit Richard O'Connor's theory that the Burman watercontrol techniques were superior to those of earlier residents, ${ }^{34}$ we may have a partial explanation for the rather gradual nature of agrarian expansion and the relatively late date of political integration under Pagan. ${ }^{35}$ In northern Vietnam, Tang collapse in the early goos drew the local elite into a tumultuous competition whose resolution under the early Ly Dynasty (1009-1225) was a precondition for political and probably economic maturation. Adaptation of Chinese-style hydraulic administration under the early Tran Dynasty (1224-1400) enhanced Dai Viet's agrarian prospects quite substantially. ${ }^{36}$

${ }^{32}$ Yumio Sakurai, 'Vietnam After the Age of Commerce' (ms), 1-3; SP, I, 362-65, 368, 420; Esta Ungar, 'Sources for Historical Demography: Vietnam from the $15^{\text {th }}$ Century' (ms); Keith Taylor, 'Authority and Legitimacy in $11^{\text {th }}-$ Century Vietnam', in David Marr and Anthony Milner, eds, Southeast Asia in the $9^{\text {th }}$ to $14^{\text {th }}$ Centuries (Singapore: Institute of Southeast Asian Studies, 1986), 139-140; Pierre Gourou, Les Paysans du Delta Tonkinois (Paris: Les Editions d'Art et d'Histoire, 1936), 65-70, $8_{3-85}, 113-121,130-135$.

${ }^{33}$ G. H. Luce, 'Old Kyaukse and the Coming of the Burmans', Journal of the Burma Research Society [henceforth JBRS] $4^{2}$ (1959): 75-109; idem, Old Burma, I, Chapter 1; Aung-Thwin, Pagan, pp. 17-22.

${ }^{34}$ Richard O'Connor, 'Agricultural Change and Ethnic Succession in Southeast Asian States', JAS 54 (1995): 968-996. Cf. Hudson, 'Origins of Bagan', 1 27, $15^{1}$; and n. 25 supra.

${ }^{35}$ At the same time raids by the kingdom of Nan-zhao in Yunnan may have increased Pyu vulnerability.

${ }^{36}$ Taylor, Birth of Vietnam, pp. 250-301; idem, 'Twelve Lords'; John Whitmore, "Elephants Can Actually Swim', in Marr and Milner, Southeast Asia $9^{\text {th }}$ to $14^{\text {th }}$ Centuries, $117-137 ; S P$, I, 353, 360-361, 364. 
But if local features help to explain early differences, they say nothing about the far more basic question: Why, amidst local variations, did all three charter states flourish between circa $95^{\circ}$ and $125^{\mathrm{O} / 1300}$ ? Why do we not find charter geneses randomly distributed between, say, the fifth and fifteenth centuries? The problem is all the more intriguing in that China, South Asia, and Europe also enjoyed generally unprecedented economic, demographic, and political vigour for much of the period between $95^{\mathrm{O}}$ and $125^{\mathrm{O} / 1} 3_{00} .^{37}$

The most obvious common factor in the Cambodian plain and the Irrawaddy basin was Indian maritime contacts, which provided a template for royal courts and temples. But this avails us little insofar as Saivite and/or Buddhist elements had been integral to both mainland cultures since at least the seventh century, while in Dai Viet, Indic influences remained marginal. Some best practices in agrarian technique and seed selection probably spread across the mainland either overland or, more probably, along the coast. But again why should diffusion have intensified after $95^{\circ}$ ? Of yet wider significance, burgeoning trade with China and South Asia after 9oo may have helped to coordinate mainland growth in three ways: (1) overseas demand encouraged specialized export crops (albeit on a yet modest scale) $;^{38}$ (2) conceivably, more frequent trade contacts joined population growth to transform once uniformly lethal epidemic diseases like smallpox into endemic afflictions of childhood. By precluding the horrendous virgin-soil effects associated with smallpox in the New World, this would have benefited those coastal and lowland districts where populations were sufficiently dense to sustain chains of infection and where exposure to foreign pathogens was most common; ${ }^{39}$ (3) more certainly, prestigious foreign goods gave

${ }^{37}$ For extended discussion and analysis, see SP, II, Chapters 1, 2, 5-6.

${ }^{38}$ On multifaceted maritime influences, see John Whitmore, 'The Rise of the Coast', JSEAS 37 (2006): 103-122; Geoff Wade, 'An Early Age of Commerce in Southeast Asia, 900-1 300 CE', JSEAS 40 (2009): 221-265, and the response to Wade by Victor Lieberman, 'Maritime Influences in Southeast Asia, c. 9oo-13oo: Some Further Thoughts', JSEAS 41 (2010): $35^{1-361 .}$

39 According to Frank Fenner, 'Smallpox in Southeast Asia', Crossroads 3 (1988): $34-35$, an interactive population of $100,000-200,000$ is usually sufficient for smallpox to become endemic. From an early date, Burma's lowland core, Angkor, and Dai Viet all had populations well in excess of this threshold. See n. 29 supra and SP I, 420, Figure 4.2. As late as the nineteenth century, smallpox still could take a serious toll in archipelagic Southeast Asia, but was far more virulent in isolated districts than in well-frequented and populous coastal areas. See Linda Newson, 'Old World Diseases 
charter states incentives ${ }^{40}$ and cash revenues ${ }^{41}$ to support agrarian expansion.

While working in synergy with these other factors, however, climate may have been the single most influential agency of charter coordination. As Figure 1 indicates, after a strong desiccative phase between 1040 and 1090 , the twelfth century saw a dramatic, possibly unprecedented increase in rainfall, with the highest PDSI values on record. The thirteenth century then divided between an unusually dry first half (note, however, that pre-1250 readings are the least reliably replicated portion of the record) and an unusually wet second half. Average PDSI values between 1030 and 1300 exceeded those for any comparable period to 1900 . These post-1030 trends are broadly consistent with records from Dandak Cave in east-central India (Figure 4) as well as with speleothem readings from Wanxiang Cave in North China. ${ }^{42}$ Moreover, although the south Vietnamese cypress series starts only in 1030, Indian, Chinese, and European records and theoretical studies indicate that the Medieval Climate Anomaly as a whole, circa 900/950-1250/1300, (a) tended to be unusually warm, (b) saw the Inter-tropical Convergence Zone stabilize some five degrees latitude north of its post-Medieval Climate Anomaly location, and (c) may have produced a persistent La Niña-like condition in the tropical Pacific. ${ }^{43}$ Historically all three conditions have been associated with increased rainfall over Southeast Asia and India. Persistent La Niñas tend to produce not merely an increase in monsoon volume, but more even annual distribution, with longer monsoons, shorter dry season

in the Early Colonial Philippines and Spanish America', in Daniel Doeppers and Peter Xenos, eds, Population and History (Madison: University of Wisconsin Center for Southeast Asian Studies, 1998), pp. 17-36; Barbara Watson Andaya, To Live as Brothers (Honolulu: University of Hawaii Press, 1993), p. 228; Boomgaard, 'Crisis Mortality in Seventeenth-Century Indonesia', especially 199-202; idem, Southeast Asia, 120; Frank Fenner et al., Smallpox and Its Eradication (Geneva: World Health Organization, 1988), 209-232; William McNeill, Plagues and Peoples (Garden City, New York: Anchor Press, 1976), Chapters. 2-4.

${ }^{40}$ Chinese and Indian Ocean luxuries encouraged agrarian expansion either because local foodstuffs could be exchanged for such imports, or because royal monopolies on exotic exports required military force, which presupposed abundant manpower, which favoured agrarian expansion.

${ }^{41}$ On international bullion flows in the late charter era, see Akinobu Kuroda, 'The Eurasian Silver Century, 1 276-1 359', Journal of Global History 4 (2009): 245-269.

${ }^{42}$ Wanxiang Cave is in Wudu County, Gansu Province. Zhang, 'Test of Climate'. Note, however, that neither Dandak nor Wanxiang records show a decline in rainfall between circa 1200 and $125^{\circ}$ as large as that in South Vietnam in Figure 1.

${ }^{43}$ See nn. 13-14 supra. 
droughts, and fewer deluges that can damage crops and irrigation works. Thus rain becomes available in more 'usable' form over a longer part of the year. All in all, these would have been ideal conditions for agricultural and political expansion, especially in those 'rain-shadow' dry zones, partially shielded from the monsoons by southwestern uplands, where both Pagan and Angkor lay.

Without Southeast Asian data prior to 1030 we cannot prove that the Medieval Climate Anomaly helped to 'jump start' charter state expansion. But given that the Dandak Cave materials (Figure 4) show extremely strong monsoons between $95^{\circ}$ and 1030, and given the long-term correlations between Dandak and southern Vietnamese cypress data (Figures 1 and 4 ), it is reasonable to assume that climatic amelioration between $95^{\circ}$ and 1030 contributed significantly, even critically, to early charter vitality across the mainland. That assumption is strengthened by the fact that our earliest currently available mainland PDSI reading, from 1030, is at a very high level (Figure 1).

After 1030 climate's contribution to charter construction is more easily demonstrated. At Pagan, Figure 6 (based on work by Bob Hudson, Nyein Lwin, and Win Maung) charts the volume of material used in religious construction between $105^{\circ}$ and $135^{\circ}$. Note that during the twelfth century, a period of greatly enhanced rainfall, building rose sharply. Given the 'ideal' climate between 1100 and $115 \mathrm{O}$, one would expect a more rapid increase than has been detected. Perhaps excessive rain impeded brick construction, perhaps some edifice dates are problematic, perhaps political conditions were unfavourable. But the overall vigour of twelfth century construction remains stunning. Slow growth during the first third of the thirteenth century and renewed expansion from around 1230-1300 also are consistent with climatic trends, although as we shall see below, ecology and politics as well as rainfall began to impose a ceiling on fresh dedications. Insofar as Buddhist wealth derived principally from landed endowments, whose opening depended heavily on climate, it is hardly surprising that reclamation also correlated broadly to rainfall. Irrigation in the 'hubs' (hkayaings) of Kyaukse and Minbu, on which initial efforts focused, relied on streams that would have benefited from enhanced monsoons between $95^{\circ}$ and 1040. Developed in the twelfth and thirteenth centuries, taik districts in Shwebo, Lower Chindwin and Pakokku lacked the same level of perennial irrigation as the 'hubs'. Yet in these frontier areas the exceptional pluviation of these two centuries would have favoured rain-fed wet rice as well as dry 


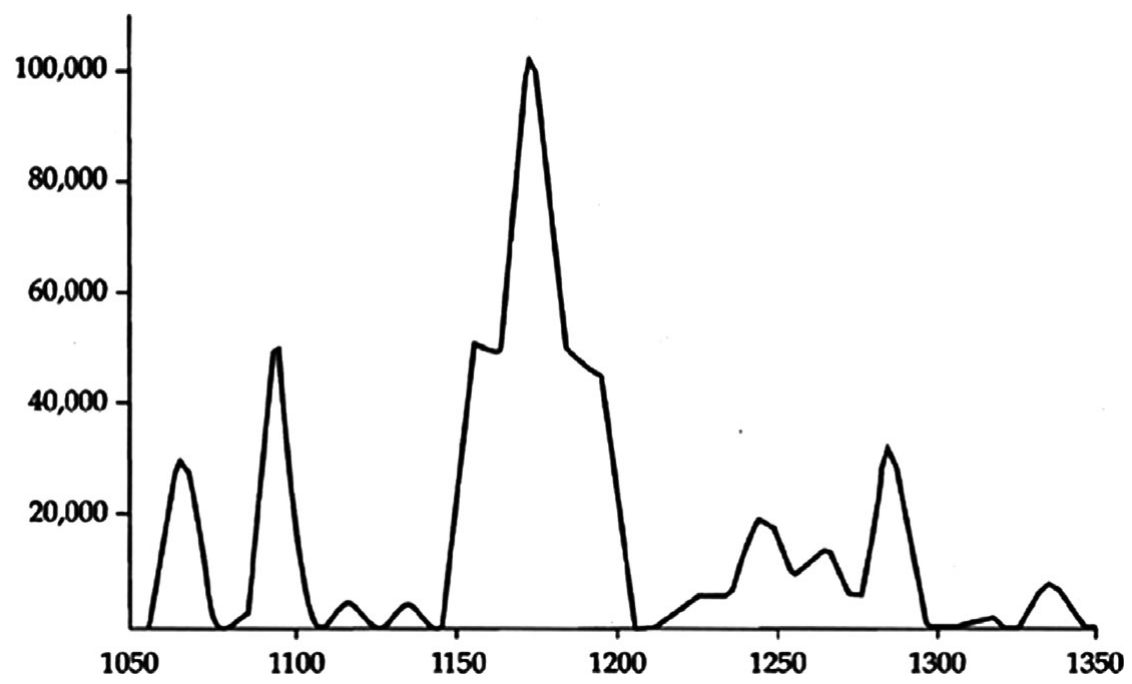

Figure 6. Religious donations at Pagan, showing cubic meters of building material used in 89 epigraphically or historically dated monuments. ${ }^{44}$

crops. In contrast to religious construction, Burmese land reclamation between 1100 and 1150 remained vigorous. ${ }^{45}$

In Cambodia improved rainfall during the latter part of Angkor's eighth to tenth-century genesis may have helped farmers move from easily cleared but comparatively unproductive sites in the Mekong delta and the Mun-Chi River floodplains, towards wooded lowlands in the same river basins and around the Great Lake. In this normally arid region ${ }^{46}$ cultivators dug ponds and enclosed hundreds of thousands of small, bunded rice fields. Under royal direction they also developed an ever more elaborate network of reservoirs, canals, moats, and irrigation channels so as to harness both the monsoons and streams dependent on the monsoons. By capturing water for release during the dry season and periods of drought, by diverting excess water to the Great Lake, and by helping to sustain a year-round high water table, these facilities, capped by the great royal barays, helped to

${ }^{44}$ Source: SPI, 109, Fig. 2.2 (bottom sector), based on manuscript version of Bob Hudson, Nyein Lwin, and Win Maung, 'The Origins of Bagan [sic]', Asian Perspectives 40, (2001), Fig. 1.

${ }_{45}$ Aung-Thwin, Pagan, pp. 101-103, 186-192. On taik expansion, see too G. H. Luce, 'Economic Life of the Early Burman',JBRS 30 (1940): 286-88; idem, Old Burma, I, 29-38, 84-92.

${ }^{46}$ Fisher, South-East Asia, p. 35; M. Nuttonson, Climatological Data of Vietnam, Laos, and Cambodia (Washington, D.C.: American Institute of Crop Ecology, 1963). 
stabilize production. They thus contributed to that vast expansion in population and religious infrastructure that defined classical Angkor. What is more, strong eleventh and twelfth-century monsoons can only have aided Khmer colonization of northeast modern Thailand, which, like Burmese taiks, was relatively arid. Although we lack construction profiles comparable to those for Pagan, it is worth noting that Angkor Wat, Angkor's most lavish structure, arose in those very decades, between 1120 and 1150 , that saw the most intense and 'usable' rainfall during the entire second millennium, and that by 1200 , after a century of ideal pluviation, the number of temples in Angkor's extended core peaked at 3000 to $35^{00} .^{47}$

To argue that improved monsoons helped Pagan and Angkor, both located in dry zones, is not difficult. But in so watery an environment as the Red River delta, where Dai Viet was centred, would not increased rainfall have been an unwelcome impediment? In fact, those who reclaimed the delta came from upland areas with limited agrarian potential that would have benefited from wetter conditions. Delta colonization under both the Ly and Tran Dynasties drew in part on communities in higher elevations like Bac Giang, Thai Nguyen, Phu Tho, and Hoa Binh, where fifth- and even tenth-month rice crops remained vulnerable to drought. By reducing famine mortality and enhancing natality, more reliable rain-fed harvests in hilly areas may have helped to create the demographic pressure that impelled delta reclamation in the first place, whilst providing the extra manpower needed for polder construction to succeed. ${ }^{48}$ Moreover, if we extrapolate from the nearby Pearl River basin, whose hilly topography resembles that of the Red River, from the twelfth to the early fourteenth centuries population pressure and slash-and-burn

${ }^{47}$ Hermann Kulke, 'The Early and the Imperial Kingdom in Southeast Asian History', in Marr and Milner, Southeast Asia $9^{\text {th }}$ to $14^{\text {th }}$ Centuries, p. 16. This compares with around 2000-2500 temples at Pagan at its height. On Angkor's agrarian/institutional system and hydraulic foundations, see nn. 24, 29, 30 supra; SP I, pp. 224-228; Higham, Givilization, pp. 5, 33, 48-49, 154-155; Jacques Dumarcay, 'Khmer Hydraulics', in Helen Ibbitson Jessup and Thierry Zephir, eds, Sculpture of Angkor and Ancient Cambodia (Washington, D.C.: National Gallery of Art, 1997), 931 oo; Christophe Pottier, 'Some Evidence of an Inter-relationship between Hydraulic Features and Rice Field Patterns at Angkor during Ancient Times', Journal of Sophia Asian Studies (1 8 (2000): 99-1 19; Roland Fletcher, 'Seeing Angkor: New Views of an Old City', Journal of the Oriental Society of Australia 32-33 (2000-2001): 1-27. If our earlier speculation that excessive rain circa $1100-1150$ impeded brick construction at Pagan has any merit, it is worth noting that ample supplies of laterite and sandstone freed Angkor from comparable constraints.

${ }^{48}$ See n. 32 supra. 
agriculture in the hills aggravated erosion, which increased the downstream flow of silt to support polders in areas like Thai Binh province, much of which was reclaimed from the sea and salt marsh. ${ }^{49}$

Furthermore, in all three realms climatically assisted population growth not only increased the charter state's military and tax base, but in autocatalytic fashion, may have hastened the domestication of smallpox by creating local chains of infection sufficient to shift that disease from epidemic to endemic status. Likewise, by enhancing local demand for foreign imports and local provision of maritime exports, lowland economic growth may have stimulated trade with China and India, with its attendant cultural and material spurs to state formation. ${ }^{50}$

Finally, although space precludes adequate consideration, the thesis of Medieval Climate Anomaly stimulus to charter expansion between circa $95^{\circ}$ and $125^{\mathrm{O} / 1300}$ gains credibility from studies showing that, in this same period, warmer climate-whether by substantially extending the growing season or by increasing monsoon flowscontributed to the unprecedented agrarian and political vitality of Kiev, of the West European high middle ages, of Song China, and of warrior-led polities across South Asia. Expanding multilateral trade across Eurasia, both overland and by sea, was in large part a symptom of this generalized prosperity. ${ }^{51}$

\section{Charter state collapse, circa $1250 / 1300-145^{0}$}

After centuries of growth, all three charter realms came under mounting internal and external pressures. In the second half of the fourteenth century these culminated in a generalized economic, political, and in some cases cultural collapse, an era of fragmentation and disorder, that contrasted sharply with the integrative thrust of the charter epoch.

To sketch briefly these events: The Upper Burma state, centred originally at Pagan, faced Mongol invasions after 1277, revolts in Lower Burma from 1287, and calamitous Shan invasions from the northern hills that climaxed between 1359-1368. (Shans were one branch of the great Tai ethno-linguistic family that includes Lao,

${ }^{49}$ Cf. n. 32 supra and Marks, Tigers, Rice, Chapters 1-2, especially pp. 29-33, 70.

${ }^{50}$ On smallpox, see n. 39 supra; and on maritime trade, n. 38 supra.

${ }^{51}$ See SP II, chs. 2, 5, 6, and nn. 9, $3^{8}$ supra. 
Siamese, and Yuan.) Thereafter the western mainland-which, even in Pagan's heyday, held a plethora of encapsulated ethnicitiesremained split between an upland zone of petty Shan states, a new Burman-dominated dry zone kingdom of Ava, and a coastal kingdom led by people of Mon ethnicity. ${ }^{52}$

In the central mainland, Angkor lost control of its western satellites in the mid and late 1200 , after which Tai attacks from the west forced the political abandonment of Angkor itself, temporarily, it would seem, at some point between $135^{\circ}$ and 1389 , and permanently by $145^{\circ}$. The central mainland thus fragmented between a rump Khmer state and a medley of Tai-led kingdoms to the west and north, among which Chiang Mai in the Ping basin, Sukhothai in the piedmont, Lan Sang in modern Laos, and Ayudhya near the coast proved pre-eminent. These geopolitical shifts were accompanied by the retreat of Angkorian high culture, as Sanskritic Hinduism yielded to Tai-mediated Theravada Buddhism, as the building of stone temples ceased, and Tai language and culture began to overshadow Khmer. ${ }^{53}$

Because Tais failed to penetrate the Vietnamese lowlands and because Dai Viet was more ethnically uniform, hence less fissiparous, than Pagan or Angkor, post-charter cultural displacements were less pronounced. Yet Dai Viet also faced something of an existential crisis, as peasant distress sparked massive uprisings from the 1340s, and Dai Viet's southern neighbour, Champa, launched raids into the Vietnamese heartland between 1361 and 1390 that destroyed the Tran Dynasty. Together, emigration, famine, disease, and Cham

${ }^{52}$ Lieberman, 'Charter State Collapse'; Paul Bennett, Conference Under the Tamarind Tree (New Haven: Yale Southeast Asia Studies, 1971), pp. 3-53; Michael Aung-Thwin, Myth and History in the Historiography of Burma (Athens, Ohio: Ohio University Center for International Studies, 1998), Chapters 3-4; idem, The Mists of Ramanna (Honolulu: University of Hawaii Press, 2005), reconstructing Mon origins; and SP, I, 1 19-39. On ethnicity under Pagan, see G. H. Luce, 'Note on the Peoples of Burma in the $12^{\text {th }}-13^{\text {th }}$ Centuries A.D.', JBRS 42 (1959): $75^{-102}$. On classification of Tais and other ethnolinguistic groups, see Frank Lebar et al., Ethnic Groups of Mainland Southeast Asia (New Haven: Human Relations Area Files Press, 1964); Jean Michaud, Historical Dictionary of the Peoples of the Southeast Asian Massif (Lantham, Maryland: Scarecrow Press, 2006).

${ }^{53}$ Fletcher, 'Seeing Angkor', 18; Mabbett and Chandler, Khmers, Chapters 15, 16; Coe, Angkor, Chapter 8; Charnvit Kasetsiri, The Rise of Ayudhya (Kuala Lumpur: Oxford University Press, 1976); David Wyatt, 'Relics, Oaths and Politics in ThirteenthCentury Siam', JSEAS 32 (2001): $3-66$; idem, Thailand: A Short History ( $2^{\text {nd }}$ edn, New Haven: Yale University Press, 2003), Chapters 3, 4; O. W. Wolters, 'The Khmer King at Basan (1371-73)', Asia Major, n.s. 12 (1966): 78-87; SP, I, 236-247. Although Angkor was more or less permanently abandoned by the mid 1400 , the idea that a Tai attack in 1431 constituted Angkor's death knell is suspect. 
attacks may have slashed Dai Viet's population from around 3,00o,ooo in 1300 to barely half that a century later. ${ }^{54}$

How shall we explain these generalized disorders? In part, they reflected longstanding institutional weaknesses, including the ability of the elite to wring concessions from rulers who depended on them for accession or religious validation. In the late Pagan period, for example, successful candidates for the throne often felt obliged to reward supporters with land grants and to countenance the conversion of royal freemen into private bondsmen. To secure political support and to acquire merit for happy reincarnations, Pagan's rulers also patronized (and allowed others to patronize) the Buddhist monkhood with permanent endowments until by 1280 the monkhood owned one to two-thirds of cultivable land, all of it tax-free. ${ }^{55}$ At Angkor as well, where successions were normally contested, politically indebted kings conferred tax-exempt acreages on aristocratic supporters, whose religious munificence began to rival that of the throne. Here, too, long term efforts to reclaim tax-free lands from aristocratic families and temples were only partly successful. ${ }^{56}$ Similarly in Dai Viet, Mongol attacks ended Sinic bureaucratic experiments in favour of a more patrimonial system in which military princes built private estates tilled by servile labourers many of whom had left village tax-rolls. In all three instances, once royal authority in the core was impaired, the empire quickly unravelled, for these were 'solar polities' in which a central sun held in unsteady orbit planets, i.e., provinces, whose autonomy tended to increase with distance. Apart from ceremonial

${ }^{54}$ On the fourteenth-century agrarian/social crisis, Sakurai, 'Age of Commerce'; O. W. Wolters, Two Essays on Dai Viet in the Fourteenth Century (New Haven: Yale Center for International and Area Studies, 1988); idem, 'On Telling A Story of Vietnam in the Thirteenth and Fourteenth Centuries', JSEAS 26 (1995): 65-74; John Whitmore, Vietnam, Ho Quy Ly, and the Ming (I37I-I42I) (New Haven: Yale Center for International and Area Studies, 1985), Chapters 1, 2; idem, 'Colliding Peoples: Tai/Viet Interactions in the $14^{\text {th }}$ and $15^{\text {th }}$ Centuries' $(\mathrm{ms}) ; S P$, I, $367-72$, 420, with population graph; and n. 32 supra and n. 81 infra.

${ }^{55}$ Victor Lieberman, 'The Political Significance of Religious Wealth in Burmese History: Some Further Thoughts', JAS 39 (1980): 753-757; Bennett, Conference, 353; Than Tun, 'History of Burma A.D. 1 300-1400', JBRS 42 (1959): 1 19-33; AungThwin, Pagan, especially Chapters 8, 9 .

56 This is my reading of I. W. Mabbett, 'Kingship in Angkor', Journal of the Siam Society 66 (1978), 1-58, especially p. 9; Higham, Archaeology, p. 355; Mabbett and Chandler, Khmers, p. 172 ; Sachchidanand Sahai, Les Institutions Politiques et l'Organisation Administrative du Cambodge Ancien (VIe-XIIIe Siecles) (Paris: Ecole Francaise d'ExtremeOrient, 1970), pp. 145-148; Donatella Mazzeo and Chiara Silvi Antonini, Monuments of Civilization: Ancient Angkor (New York: Grosset and Dunlap, 1978), pp, 64-81, 168173 . 
ties and the ever less credible threat of military chastisement, in Pagan and Angkor, in particular, there was no way to ensure the loyalty of formerly independent kingdoms, whose rulers often aped the ritual claims of the capital. ${ }^{57}$

In each imperial core cumulative ecological stress, itself partly a function of Medieval Climate Anomaly vitality, hastened political devolution. In the heartland of Upper Burma the most critical resource was never land per se, rather irrigable land. But by the mid 1200 a pronounced reduction in donations suggests that reclamation already had reached or was approaching the limit of available water resources. ${ }^{58}$ As the population continued to grow, the declining quantity and quality of per capita arable led more impoverished freemen to seek security as bondsmen on religious and lay estates. If this offered immediate benefits to some estate owners, in the long term peasant immiseration reduced the surplus and intensified intraelite factionalism.

Resource limitations were at least as debilitating at Angkor, albeit with a peculiar twist focusing on the unusually elaborate hydraulic system. If some aspects of his thesis remain controversial, ${ }^{59}$ paleoecologists and archaeologists have now confirmed much of Bernard Groslier's bold hypothesis, advanced over 35 years ago, that Angkor fell victim to ecological strains. ${ }^{60}$ In the eleventh and twelfth centuries, as the search for fuel, building materials, and perhaps fresh arable land pushed peasants to clear forests ever farther north of Angkor in the Kulen hills, erosion and sedimentation began clogging streams and canals connected to the royal barays. Although these reservoirs supplied primary irrigation to only a small portion of Angkor's rice fields, they helped to stabilize overall production, as

${ }^{57}$ Royal authority in Dai Viet decayed even though the Tran, alone among Southeast Asian ruling families, instituted royal primogeniture. See n. 54 supra; O. W. Wolters, 'What Else May Ngo Si Lien Mean?' in Anthony Reid, ed., Sojourners and Settlers (St Leonards, Australia: Allen and Unwin, 1996), pp. 107-1 10. On the administrative structure of Southeast Asian charter states generally, see SP I, Chapters 2-4.

${ }^{58}$ See Figure 6 on temple construction, and Aung-Thwin, Pagan, pp. $187-189$, on gifts of land, labour, and silver. After three centuries of reclamation, it appears that still only about 6 per cent of Upper Burma was given to rice, and another 6 per cent to dry crops. Lieberman, 'Political Significance', pp. 754-755.

59 See, e.g., the critique by Fukui Hayao, 'Groslier's Hydraulic Society Theory of Angkor in the Eyes of an Agroecologist', Southeast Asian Studies 36 (1999): 546-554.

${ }^{60}$ Bernard Groslier, 'Agriculture et religion dans l'empire Angkorien', 'Etudes Rurales $53^{-5} 5^{6}$ (1974): 95-1 1 7, especially p. 105; idem, 'La cite hydraulique', Bulletin de l'Ecole Francaise d'Extreme-Orient 66 (1979): 161-202, especially pp. 191-195; Mabbett and Chandler, Khmers, $15^{1-153}, 214^{-215}$. 
noted, by blunting seasonal floods, by providing water in the dry season and during droughts, and by sustaining a year-round high water table necessary for wells, ponds, and canals. As repeated breaches and only partly successful repairs suggest, erosion, sedimentation, and the sheer difficulty of maintaining an ever more convoluted system began to impede all three functions, even in Angkor's heyday. By the early 1200 s the West Baray, for example, was going dry. ${ }^{61}$ What is more, accumulating phosphates from human and animal waste may have joined lakeside deforestation to impair those lake fisheries that supplied Angkor's population with its chief source of protein. ${ }^{62}$ As in Upper Burma, such pressures apparently began to reduce settlement and population, ${ }^{63}$ to intensify factionalism, and thus to leave the realm vulnerable to Tai incursions.

Dai Viet too suffered cumulative resource constraints. In the late 1200 , by which time, recall, the population was almost twice that of 1000 , new tracts became more marginal and reclamation began to stall. This slowdown joined land engrossment by princes and other notables to depress peasant income, which not only accelerated the transformation of taxpayers into servile labourers, but as the annals show, from 1343 prompted repeated uprisings by starving vagabonds and monks championing such slogans as 'Relieve the impoverished people'. ${ }^{64}$

In short, in one locale after another some 3 oo years of growth began to produce, if not Malthusian crises per se (more equitable land distribution probably would have alleviated peasant distress), then severe political and ecological strains. Reduced temple construction at Pagan, deforestation of the Kulen Hills and hydraulic difficulties at Angkor, peasant distress in Dai Viet, and sputtering reclamation

${ }^{61}$ Less favourable rainfall also may have been a factor. Fletcher, 'Seeing Angkor', p. 22; Richard Stone, 'The End of Angkor', Science 311 (2006): 1364-1368; Fletcher and Daniel Penny, personal communications, 13-14January 2011. On the operation and degeneration of Angkor's hydraulic system, see too Ortloff, Water Engineering, 358-376, 399; Dumarcay, 'Khmer Hydraulics'; Penny, 'Vegetation and Land-Use'; Fletcher, 'Development of Water Management'; Pottier, 'Evidence of an Interrelationship'; Greater Angkor Project, 'Redefining Angkor'; Evans, 'Comprehensive Archaeological Map'; Leigh Dayton, 'The Lost City', New Scientist, 13 January 2001 : 43-46; Buckley, 'Climate As a Contributing Factor'; Richard Stone, 'Divining Angkor', National Geographic 216 (2009): 26-55, especially 49-51.

62 This suggestion appears at Fletcher, 'Seeing Angkor', pp. 22-24.

${ }^{63}$ Cf. Evans, 'Comprehensive Archaeological Map', p. 14282.

${ }^{64}$ In 1389 an army of vagabonds occupied the capital for three days. Notes 32, 54 supra; SP, I, $367-371,420$. 
in all three realms attested to the ecological dimension. In all three realms internal debility naturally encouraged - and was exacerbated by-provincial defections and external attacks. Indeed, insofar as major provinces retained traditions of independent sovereignty, the distinction between external attacks and imperial defections could be quite nominal. The pronounced localism of ethnic and religious identities - an inevitable by-product of popular illiteracy and weak market and political linkages-further inhibited capital-centred loyalties such as we shall find helped to stabilize post-charter realms.

But why across the mainland did institutional and ecological strains that had been building for some time become acute in the third quarter of the fourteenth century? What seems to have converted still manageable tensions into uncontrolled crises was the aforementioned transition from the Medieval Climate Anomaly to the Little Ice Age. By dragging the Inter-tropical Convergence Zone five degrees of latitude south (where it remained until the latter half of the nineteenth century), the Little Ice Age helped to diminish the geographic reach of summer monsoons. If a La Niña-like base-state in the tropical Pacific characterized the Medieval Climate Anomaly, the Little Ice Age may have been dominated by persistent El Niño conditions. Thus, whereas the Medieval Climate Anomaly had produced decidedly above average monsoon volume, during the Little Ice Age droughts became far more frequent and prolonged. ${ }^{65}$ As Figure 1 shows, rainfall diminished notably in the early 1200 , improved after $125^{\circ}$, but declined sharply in the fourteenth century, reaching a low point around 1340-1380the very years that saw major invasions and/or domestic upheavals in Burma, Dai Viet, and Angkor. In each realm it was these mid and late fourteenth century disturbances-Shan invasions in Upper Burma, Tai invasions and the first putative abandonment of Angkor, peasant revolts and Cham invasions in Dai Viet-that effectively terminated the charter era. After a brief respite, desiccation resumed for most of the period from circa $1390-145^{\circ}$ and from circa 1470-1490. All in all, of the 40 most negative annual PDSI scores in the 1ooo-year long south Vietnamese cypress record, six fell in the mid and late 1300 and seven in the early 1400 . In much of monsoon Asia a mere 10 per cent reduction in seasonal rainfall is sufficient to trigger a major drought, but in the fourteenth century these so-called Angkor Droughts may have seen a $20-30$ per cent reduction (relative to the

${ }^{65}$ See nn. 61 supra and 70 infra. 
modern climatological mean) and lasted $30-40$ years. ${ }^{66}$ These treering patterns are consistent with speleothem records from India and North China and with chronicle notices of severe drought from north eastern Burma, northern Thailand, and northern Vietnam. ${ }^{67}$

Not only did the volume of the monsoons diminish for long periods, but new distribution patterns may have rendered such rains as did fall less accessible. The Medieval Climate Anomaly, we saw, was characterized by relatively gentle monsoons spread across a substantial part of the year, with limited dry season droughts, conditions that may have favoured double-cropping. In contrast, Little Ice Age monsoons probably were more volatile and more concentrated in short annual periods with high magnitude deluges. Thus northern Burma, northern Thailand, northern Vietnam, and Cambodia saw droughts broken by occasional freak floods from the 1290 s to the late 1300 and in the first half of the fifteenth century. ${ }^{68}$

Such conditions would have eroded royal legitimacy—since the ruler was responsible for maintaining cosmic harmony-whilst shifting power to more hydrologically secure districts. In Upper Burma the transfer of the royal capital from Pagan to Myinsaing, Pinya, Sagaing, and finally to Ava (1365) may have owed much to the fact that the latter four sites all lay closer than Pagan to perennially irrigated Kyaukse. Subsequently on the southern fringes of the dry zone, better watered districts like Prome and Toungoo began to enhance their authority at Ava's expense; and within the lowlands as a whole, Lower Burma, with average annual rainfall over three times higher than in the dry zone, achieved a novel pre-eminence. Indeed, the new Mon-led

${ }^{66}$ Buckley, 'Climate as a Contributing Factor', 6748; Sinha, 'A Global Context for Megadroughts', 13-14.

${ }^{67}$ See Figure 4; Zhang, 'Test of Climate'; Sao Saimong Mangrai, The Padaeng Chronicle and the Jengtung State Chronicle Translated (Ann Arbor: University of Michigan Center for South and Southeast Asian Studies, 1981), 141-142, 237-238, referring to severe droughts in 1392-1393 and 1410-141 1; Whitmore, Ho Quy Ly, 33-34, 37, referring to the same drought in 1392-1393; Buckley, 'Climate as a Contributing Factor', nn. 16-18, citing a Chiang Mai chronicle and noting that these droughts may have extended to Sri Lanka, India, and central China.

${ }^{68}$ Previous note, plus Buckley, 'Climate As a Contributing Factor', including the appendix 'Supporting Information'; David Godley, 'Flood Regimes in Northern Thailand' (Monash University, M.A. Thesis, 1997), 140-142; Inscriptions of Pagan, Pinya and Ava (Rangoon: Superintendent, Government Printing, Burma, 1892), p. 325 . 
Lower Burma kingdom of Ra-manya, whose capital would settle at Pegu, detached the entire south from Upper Burma's authority. ${ }^{69}$

At Angkor, the combination of recurrent drought and episodic deluge proved particularly damaging to the fragile hydraulic infrastructure, which, as we saw, in the early 1200 already was working at reduced capacity. Between circa 1290 and 1340 severe floods cascaded through the system, inflicting what seems to have been irreparable damage, whilst droughts in the fourteenth and fifteenth centuries reduced further the system's basic supply. ${ }^{70}$

To repeat, tensions rooted partly in Medieval Climate Anomaly growth had been present for decades, but now across the mainland climate intensified and synchronized those strains to the point of undisguised rupture. Traditionally scholars have explained the 'fall' of Pagan, Angkor, and Dai Viet by focusing on local, sui generis politics and institutions. Now climate, for the first time, helps to provide a coherent regional narrative.

To the direct impact of climate, however, we must add two other mechanisms of coordinated collapse: Tai incursions and maritime trade. Both were influenced by climate, although neither can be reduced to a function of climate.

Moving south and west from what are now South China and northern Laos, in the eleventh century illiterate Tai 'valley wanderers' entered the orbit of Pagan and Angkor as mercenaries and lowlevel tributaries. Four factors now allowed some of these groups to exploit charter state debility with dramatic success. ${ }^{71}$ First, Tais enjoyed martial skills typical of rough-hewn frontiersmen. Second, Tai statelets benefited in the late 1200 s from Mongol patronage and from

${ }^{69}$ This is not to deny that maritime trade probably constituted a more significant source of Lower Burma strength than did agriculture. See discussion infra, and U Kala, Maha-ya-zawin-gyi, vol. 1, Saya Pwa, ed. (Rangoon: Han-tha-wadi Pi-ta-kat Press, 1960), pp. 283-287, 375-440; SP, I, 1 29-131.

70 Note 61 supra, plus Richard Stone, 'Tree Rings Tell of Angkor's Dying Days', Science 323 (2009): 999; Jared Diamond, 'Maya, Khmer and Inca', Nature 461 (24 September 2009), 479-480; Cook, 'Asian Monsoon Failure'; (Anonymous) 'Did Climate Influence Angkor's Demise?', Science Daily, zo March 2010.

${ }^{71}$ On Tai history to circa 1400, Wyatt, Thailand, Chapters 1-4; idem, 'Relics, Oaths'; Martin Stuart-Fox, The Lao Kingdom of Lan Xang: Rise and Decline (Bangkok: White Lotus, 1998), Chapters 1-2; G. Coedes, The Indianized States of Southeast Asia, Walter F. Vella, ed. (Honolulu: East-West Center, 1968), Chapter 1 2; Tatsuo Hoshino, Pour une Histoire Medievale du Moyen Mekong (Bangkok: Editions Duang Kamol, 1986); Srisak Vallibhotama et al., 'Siam Before the $14^{\text {th }}$ Century', in Varunyupha Snidvongs, ed., Essays in Thai History (Singapore: Institute of Southeast Asian Studies, 1991); Nidhi Eiosrivongs et al., 'Early Ayudhya', in Snidvongs, Essays; Kasetsiri, Rise of Ayudhya. 
Mongol pressure on Pagan, Angkor, and Nan-zhao (in Yunnan). Third, Tais apparently enjoyed superior agricultural techniques. Not only did they disseminate productive new rice strains, but O'Connor argues that upland water management skills let them (like Burmans in an earlier age) occupy a range of niches beyond the flood-land edge where previous cultivators had dwelled. ${ }^{72}$ The superiority of this agrarian complex led many non-Tais to accept the newcomers' language and social conventions, in effect, to become Tais, thereby swelling Tai ranks more rapidly than natural growth alone would have done. ${ }^{73}$ Finally, Tais probably benefited from the Medieval Climate Anomaly. On the one hand, during the ideal monsoon conditions of the twelfth and late thirteenth centuries proliferating Tai-lowland economic interactions provided Tai monks, traders, mercenaries, and chiefs with the cultural capital-Buddhist literacy, models of kingship—that was critical to rule sedentary populations. Not surprisingly, Tai states most familiar with charter civilizations proved best able to exploit post-1250 turmoil. ${ }^{74}$ On the other hand, successful Tai kingdoms like Chiang Mai, Chiang Saen, Phayao, even Sukhothai lay in rain-shadow zones that profited from the unusual reach and duration of monsoons to circa 1300. Most such places could have flourished only under a climatic regime very different than that of today.

At the same time as Tai pressure weakened charter states from the interior, rising maritime trade prompted defections at the coast. Between circa $95^{\circ}$ and 1280 in India, South China, Europe, and other sectors of Eurasia, benign conditions associated with the Medieval Climate Anomaly contributed to agrarian-cum-population growth, which in turn swelled the demand for foreign luxuries, hence the volume of east-west traffic passing through Southeast Asian waters. ${ }^{75}$

72 We follow O'Connor, 'Agricultural Change', plus Yoneo Ishii, ed., Thailand: A Rice-Growing Society (Honolulu, 1978); Tadayo Watabe, 'The Glutinous Rice Zone in Thailand', in Shinichi Ichimura, ed., Southeast Asia: Nature, Society, and Development (Honolulu: University of Hawaii Press, 1977), 96-113; Yoshikazu Takaya, 'An Ecological Interpretation of Thai History', JSEAS 6 (1975): 190-195.

${ }^{73}$ Previous note plus Wyatt, Thailand, 30-6o; Kasetsiri, Rise of Ayudhya, Chapter 3; Betty Gosling, A Chronology of Religious Architecture at Sukhothai (Ann Arbor: Association for Asian Studies, 1996), p. 4 .

${ }^{74}$ See nn. 71-73 supra.

${ }^{75}$ Institutional, technological, and political factors also joined climate to boost international trade. See n. 38 supra; Janet Abu-Lughod, Before European Hegemony: The World System A.D. I250-1350 (Oxford: Oxford University Press, 1991); Jan Wisseman Christie, 'The Medieval Tamil-Language Inscriptions in Southeast Asia and China', JSEAS 29 (1998): 239-268; Billy K. L. So, Prosperity, Region, and Institutions in Maritime 
Mainland ports that provided entrepôt services and exchanged forest exotica and other local specialties for imported handicrafts and metals thus increased their authority at the expense of interior centres. Between circa 1280 and 1400 some scholars claim that Eurasian population losses, the Mongol diversion of trade overland, and Ming restrictions depressed Southeast Asian maritime trade. ${ }^{76}$ Others argue that Eurasian demographic decline had little impact onindeed may have favoured-those luxury trades in which Southeast Asia specialized. ${ }^{77}$ But even if the pessimists are right that trade fell in absolute terms, given the severity of Southeast Asia's post-1300 agrarian crises, in the fourteenth century the relative contribution of maritime commerce to regional political economies almost certainly increased. What is more, the mid fifteenth century inaugurated a vigorous maritime expansion.

In synergy with climate and Tai attacks, maritime defections thus became a key element in charter collapse. Trade probably contributed more substantially than agriculture to the growing power of Ramanya in Lower Burma, whose agrarian population actually seems to have been quite thin. ${ }^{78}$ In the central mainland Angkor became the principal victim of this same maritime shift, while Suphanburi, Ayudhya, and Phnom Penh, all relatively near the sea, were amongst the main winners. ${ }^{79}$ In the eastern lowlands as well, Champa benefited

China (Cambridge, Massachusetts: Harvard University Asia Center, 20oo), Part 1; and $S P$, II, Chapters 2, $5^{-7}$.

${ }^{76}$ For evidence of a post-1 280 downturn, see Wade, 'Early Age of Commerce', 228, 238-239; Reid, Age of Commerce, 10-53; idem, 'Flows and Seepages in the Long-Term Chinese Interaction with Southeast Asia', in Reid, Sojourners and Settlers, pp. 15-37; David Bulbeck et al., comps, Southeast Asian Exports Since the $14^{\text {th }}$ Century (Leiden: KITLV Press, 1998); Roxanna Brown, 'A Ming Gap?' in Geoff Wade and Sun Laichen, eds, Southeast Asia in the Fifteenth Century: The China Factor (Singapore: NUS Press, 2010), 359-383.

77 Moreover, Sino-Southeast Asian ceramics filled much of the gap caused by declining Ming ceramic exports. See Mabbett and Chandler, Khmers, 215-216; Whitmore, 'Rise of the Coast'; Kenneth Hall, 'Local and International Trade and Traders in the Straits of Melaka Region: 60o-150o', Journal of the Economic and Social History of the Orient 47 (2004): 213-260; and Roderich Ptak, 'From Quanzhou to the Sulu Zone and Beyond', JSEAS 29 (1998): 269-294.

${ }^{78}$ Victor Lieberman, Burmese Administrative Cycles: Anarchy and Conquest, c. $1580-1760$ (Princeton: Princeton University Press, 1984), pp. 17-18.

${ }^{79}$ Michael Vickery, 'Cambodia After Angkor: The Chronicular Evidence for the $14^{\text {th }}$ to $16^{\text {th }}$ Centuries' (Yale University Ph.D. Dissertation, 1978), pp. 491-522; idem, 'The 2/K.125 Fragment, A Lost Chronicle of Ayutthaya', JSS 65 (1977): 78 8o; Mabbett and Chandler, Khmers, 179-182, 215 $5^{-216}$; Charnvit, Rise of Ayudhya, Chapters 4-7; Wyatt, Thailand, Chapters 3-4. 
in the late 13 oos from the tendency of Chinese shipping to bypass northern Vietnam in favour of the Cham coast, which specialized in rare forest products. ${ }^{80}$

We note in passing that the Medieval Climate Anomaly-Little Ice Age transition also contributed to fourteenth-century crises in Europe, China, and India. The same decades (1340-1380) as collapsed Upper Burma, Angkor, and Dai Viet saw the nadir of French fortunes during the Hundred Years War, the fall of the Yuan Dynasty, and the effective collapse of the Delhi Sultanate. In each case climatic deterioration magnified in complex ways long-standing institutional and/or ecological vulnerabilities. ${ }^{81}$

\section{Climate and political reintegration, $\operatorname{circa} 145^{0-1610}$}

During the 'early modern' era of mainland history, circa $145^{\circ-1820}$, climate remained influential, but less so than during the previous five centuries. As our introduction and Figures 1 to 3 suggest, after about $145^{\circ}$, with the partial exception of the eighteenth century, multidecadal rainfall fluctuations became less pronounced than during the Medieval Climate Anomaly and the early Little Ice Age. Moreover, multiple forces-economic intensification and diversification, firearms, institutional refinements, wider cultural circulation-sheltered post-1 $45^{\circ}$ states and societies more effectively against dislocation. Thus, whereas climate continued to oscillate, in all three sectors of the mainland, political and cultural integration tended to progress in more or less linear fashion.

Consider first the period circa $145^{\mathrm{O}-1610}$, whose coherence derived from the fact that in each sector these years saw the first sustained post-charter political revival. In each sector, moreover, post-charter experiments ended in the late $15^{\mathrm{Oos}}$ with a second generalized

${ }^{80}$ This is not to deny that Dai Viet also drew some profit from Song and Yuan trade. Momoki Shiro, 'Dai Viet and the South China Sea Trade Boom from the $10^{\text {th }}$ to the $15^{\text {th }}$ Century', Crossroads 12 (1998); John Whitmore, 'Van Don, the 'Mac Gap,' and the End of the Jiaozhi Ocean System', in Nola Cooke et al., eds, The Gulf of Tongking Through History (Philadelphia: University of Pennsylvania Press, 201 1), pp. 101-1 16; idem, 'Rise of the Coast'.

${ }^{81}$ See extended discussion in SP, II, Chapters 2, 5, 6; Lieberman, 'Charter State Collapse'. On the other hand, there is little current evidence that the Black Death seriously impacted Southeast Asia or India; it also may have bypassed China. Lieberman, 'Charter State Collapse', nn. 73, 74; Boomgaard, Southeast Asia, p. 120. 
collapse, albeit in the west and centre a collapse far shorter and less disruptive than that which closed the charter era.

Lieberman's claims for improved climate between circa 1470 and 1590 now may be seen as overstated, ${ }^{82}$ because although conditions ameliorated, by and large the desiccation characteristic of the early Little Ice Age persisted. In the western and central mainland this continued to privilege well-watered districts along the perimeter of the old charter empires at the expense of their dry-zone cores.

Thus in the Irrawaddy basin low rainfall continued to weaken the interior, where Ava had succeeded to Pagan's authority, to the benefit of the coast and newly risen principalities along the southern fringes of the dry zone midway between Ava and the coast. In the latter districts the aforementioned states of Prome and Toungoo expanded tanks and feeder canals and benefited from a more productive, waterintensive rice strain known as kauk-gyi. Lying outside the charter heartland where land had been alienated to religion for 400 years, these southern principalities also faced fewer monastic claims to tax exemption than did Pagan or Ava. As a beneficiary of ecological realignment, as the chief refuge of Burmans fleeing disorders in the north, and as proud heir to Burman (as opposed to Mon or Shan) ethnic traditions, Toungoo emerged as the strongest state in the western mainland, conquering Lower Burma in 1539 and the entire western mainland by $155^{8}$. After taking Lower Burma, rulers of the so-called First Toungoo Dynasty (1486-1599) moved their capital to Pegu, near the coast, which besides being a major port, lay in a rice surplus area favoured by both rainfall and riverine overflow. First Toungoo kings would remain at Pegu until their dynasty fell at the close of the sixteenth century. In short, in the western mainland between $145^{\circ}$ and 1600 Little Ice Age climate helped-we shall emphasize shortly the limits to that contribution-to pull the political centre of gravity ever farther south. ${ }^{83}$

A similar pattern characterized the central mainland, with Ayudhya near the coast playing the role of Toungoo and Pegu, and with Angkor and interior Tai kingdoms playing the part of Burmese dry zone centres. Founded circa $135^{1}$ near the frontier of the old Angkorian empire at the southernmost habitable extension of the Chaophraya basin, Ayudhya (capital of the future Siam) controlled what became

${ }^{82}$ See n. 3 supra.

${ }^{83}$ On political shifts circa $145^{\mathrm{O}-1600}$, pre-16oo ecology, and Toungoo's rise, see Lieberman, Burmese Administrative Cycles, $15^{-3} 8$; SP, I, $123^{-1} 54$. 
the central mainland's most productive agrarian sector. In the lower Chaophraya basin, where rainfall was supplemented by alluvial floods from five major rivers, excess, not dearth, was the chief hydrological problem. Given the development of floating rice in the deep-water belt below Ayudhya and the suitability of the delta north of Ayudhya for high-yield rice strains similar to Burmese kauk-gyi, cultivation around Ayudhya was capable of considerable extension. By 1400 , the Little Ice Age had helped to destroy Angkor's hydraulic system. Nor in the long term could new Tai centres in what is now north-central Thailand rival Ayudhya, in part because Little Ice Age desiccation rendered their agrarian base ever more inadequate. Although Chiang Mai, for example, called itself 'A Million Ricefields' (Lan Na), in fact it lay in a constricted basin that received only 75 per cent as much rainfall as Ayudhya and that lacked the same bountiful enrichment from annual floods. ${ }^{84}$

Between 1378 and $15^{23}$ Ayudhya triumphed over interior Tai states in bitter contests to control export staples and population clusters on the northern fringe of the central plain. Ayudhya also forced Cambodia on the defensive, notwithstanding the southward shift of the Khmer capital to the Phnom Penh area. Thus Ayudhya became the new regional hegemon. These triumphs joined population growth, wider monastic education, and market linkages to meld from Tai, Khmer, and Mon elements a novel Siamese ethnicity, which afforded Ayudhya's realm a growing psychological and cultural solidity. ${ }^{85}$

As the western and central mainland began to cohere under Toungoo/Pegu and Ayudhya, respectively, a revived Dai Viet unified most of the eastern littoral. In 1471 the new Lê Dynasty (14281788) effectively destroyed its proud southern rival, Champa, opening formerly Cham areas to Vietnamese settlement. Accelerating from the mid 15 oos, Vietnamese colonization drew strength from a remarkable demographic recovery. Between 1417 and 1539 northern Vietnam's registered population rose from 1,862, ooo to 5,625 , ooo. Although it is unclear to what extent this increase reflected improved registration, as opposed to actual population growth, Li Tana is certain that population by 1540 easily surpassed its charter-era peak,

${ }^{84}$ Chiang Mai's southern neighbour Sukhothai was similarly disadvantaged vis$a-v i s$ Ayudhya. On ecology and politics in the central mainland circa $145^{\mathrm{O}-1} 55^{\circ}$, see Kasetsiri, Rise of Ayudhya, Chapters 4-7, especialy pp. 18, 78; Wyatt, Thailand, Chapter 4; SP, I, 242-274; David Wyatt and Aroonrut Wichienkeeo, The Chiang Mai Chronicle (Chiang Mai: Silkworm Books, 1995), Chapters 4-5.

${ }^{85} S P, \mathrm{I}, 263^{-274}$. 
providing the land-hungry recruits needed to 'open the mountains and cut through the rocks' of the southern frontier, as the saying went. ${ }^{86}$

In Vietnam, however, climate's contribution to political integration was weaker than in the western or central mainland, where, we just argued, desiccation helped to drain power to well watered coastal districts. True, along the eastern littoral as well, migration proceeded from northern Vietnam to normally wetter territories farther south. Yet whereas everywhere else charter heartlands languished after $145^{\circ}$, in the east it was precisely Dai Viet's ancient core that was most demographically and politically vital. Admittedly, too, between circa 1490 and 1600 tree-rings suggest that rainfall became heavier in northern Vietnam than elsewhere on the mainland. ${ }^{87}$ But by itself this upturn seems far too modest to explain Dai Viet's remarkable late fifteenth and sixteenth-century vigour. ${ }^{88}$

What influences other than climate, then, were at work? ${ }^{89}$ Vietnamese merchants and artisans profited from expanding maritime trade, particularly with China. More basic, from 1427, Vietnam enjoyed almost a century of peace. Villages beyond the polder cores had been the first to empty out during the turmoil of the fourteenth century. Now, with more settled conditions, peasants not only reoccupied those sites, but resumed their push into virgin lands. Having embraced quasi-bureaucratic Ming administrative models, the new Lê Dynasty promoted reclamation and provided a military

${ }^{86}$ Phrase from Nguyen Tu Chi, 'The Traditional Vietnamese Village in Bac Bo', Vietnamese Studies 61 (n.d.): 40-41; and population figures from Li Tana, Nguyen Cochinchina (Ithaca: Cornell University Southeast Asia Program, 1998), pp. 159-

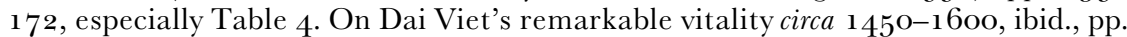
20-24, essays by Nguyen The Anh and Po Dharma in P. B. Lafont, ed., Les Frontieres du Vietnam (Paris: Editions l'Harmattan, 1989); Sakurai, 'Age of Commerce'; John Whitmore, 'The Development of Le Government in Fifteenth-Century Vietnam' (Cornell University Ph.D. Dissertation, 1968), Chapter 6; Wade and Sun, Southeast Asia in the Fifteenth Century, Part 2; SP, I, 380-399, 420.

${ }^{87}$ Rainfall data for $147^{0}-15^{80}$ in Figure 2 accord with the 'wetness index' for Guangzhou. See $S P$, I, $3^{8} 5$, nn. 120-1 23, and Marks, Tigers, Rice, 200, Figure 6.3.

${ }^{88}$ Similar problems becloud Lao historiography. There, too, in the late 1400 and 15 oos, the demographic centre of gravity moved south from the narrow valleys of northern Laos into more fertile, well watered regions of the central Mekong, focused on Vientiane, which receives about a third more rainfall than Luang Prabang. But why, judging from Figure 2, should these shifts have accelerated at a time when rainfall in Laos, as in northern Vietnam, improved somewhat?

${ }^{89}$ For a fuller discussion see SP, I, 377-393; Whitmore, 'Development of Le Government'; Wade and Sun, Southeast Asia in the Fifteenth Century, Part 2; Sun Laichen, 'Military Technology Transfers from Ming China and the Emergence of Northern Mainland Southeast Asia (c. 1390-1527)', JSEAS 34 (2003): 495-517. 
shield behind which colonization could proceed. Lê infantry deployed Chinese-style firearms to good effect. But if multifaceted Sinic-style state strengthening favoured agrarian expansion, the reverse was also true. Economic growth swelled the government's tax base and, by supporting wealthy peasants and modest landowners, provided a social foundation for the anti-aristocratic Neo-Confucian revolution of the fifteenth and sixteenth centuries. Along with wider literacy, market integration, and state patronage, such developments recast Vietnamese ethnicity and disseminated elite cultural and social norms vertically as well as horizontally.

In the western and central mainland, too, although climate influenced agrarian productivity more obviously than it did in Vietnam, we would emphasize that it was but one of several spurs to coastal ascendancy - and not necessarily the most critical. Indeed, despite Lower Burma's military eclat, for most of the sixteenth century Lower Burma's demographic/agrarian base probably remained inferior to that of the dry zone. In addition to the Little Ice Age climate, Toungoo Burma and early Ayudhya owed their success to factors that, in distinct local permutations, recall Vietnam's expansion between $145^{\circ}$ and 1600 .

First were maritime contacts. Lubricated by Japanese and New World silver, and responding to vigorous demands from Europe, China, South Asia, and Japan, Southeast Asian commerce rose sharply between $145^{\circ}$ and 1620 . In essence, their monopoly position athwart riverine outlets enabled Pegu and Ayudhya to dictate terms of trade to multiple interior centres. ${ }^{90}$ From the 1520 os coastal trade also gave ports a monopoly on European firearms, reminiscent of Chinese weapons in Vietnam, which played a major role in unification wars. In other words, the same coastal areas that benefited from the Little Ice Age climate also benefited from trade and the arrival of guns-which makes isolating the effects of climate exceedingly difficult. Second, in the west and centre, as in Vietnam, recovery from antecedent disorders gradually enhanced each state's resource base. Third, again as in Vietnam, royal support for reclamation and trade reinforced local economic initiatives. Likewise, royal patronage joined new trade circuits and rising literacy to encourage ethnic and religious standardization, providing each state with a more

${ }^{90}$ A more attractive downriver commercial location also helps to explain the rise of Vientiane over Luang Prabang. This helps to answer the problem posed in n. 88 supra. 
secure cultural base. Finally, although Burma and Siam lacked administrative blueprints such as Vietnam had borrowed from Ming China, trial and error favoured critical improvements on charterera administration, including novel curbs on religious wealth and institutions. In particular, facilitated by wider commercialization, a shift in religious donations from permanent tax-free lands to cash and handicrafts reduced the problem of monastic autonomy that had helped to cripple Pagan. ${ }^{91}$

Nor can we accord climate the same primary responsibility for coordinated political breakdown across the mainland during the second half of the sixteenth century as during the late charter era. Coordination became striking indeed: in 1555 Ava, in $155^{8}$ Chiang Mai, in $15^{69}$ Ayudhya, in 1572 Lan Sang (Laos), and in 1599 Pegu all fell to invasions; whilst between circa 1540 and 1610 Vietnam endured what Li Tana terms 'perhaps the longest period of disaster in [its] history'. ${ }^{92}$

In some cases, it is true, climate probably contributed to these difficulties. In Figure 3, Thai tree-rings point to decidedly weak monsoons in the second half of the sixteenth century, whilst chronicles from Kengtung, Lower Burma, and northern Vietnam refer to politically destabilizing droughts and famines in 1574 and the $1590{ }^{93}$ Suggestive, too, were wretchedly destabilizing climates between $15^{84}$ and 1610 in western Europe, Russia, China, and India. In fact 1601 may have been the coldest summer in the northern hemisphere for 600 years. ${ }^{94}$

And yet Figure 1 shows that late sixteenth-century PDSI average values, although low compared with the Medieval Climate Anomaly, were higher than between $145^{\circ}$ and $155^{\circ}$, when Toungoo/Pegu, Ayudhya, and the early Lê polity all displayed a lusty, adolescent vigour. What is more, in the north Vietnamese heartland between circa 1540 and 1610 political disorder coincided with rainfall heavier

${ }^{91} S P, \mathrm{I}, 13^{1-1} 54,242-274$.

${ }^{92} \mathrm{Li}$, Nguyen Cochinchina, pp. 162, 159-163, 172. Ensuing discussion follows also SP, I, 154-157, 263-277, 394-399.

${ }_{93}$ Mangrai, Padaeng Chronicle, p, 247; U Kala, Maha-ya-zawin-gyi, vol. 3, U Hkin So., ed. (Rangoon: Han-tha-wadi Pi-ta-kat Press, 1961), 92-99; SP, I, $15^{6-}$ 157 .

${ }_{94}$ On adverse climate in Europe, Russia, India, and China circa ${ }_{1} 5^{84-1610}$, see Atwell, 'Volcanism', 56-62 (with claim for 1601 summer); SP, II, 238-240; Grove and Chappell, El Niño, pp. 14-15; and especially Zhang, 'Causality Analysis of Climate Change'. 
than found elsewhere on the mainland. None of this is compatible with a primarily, much less exclusively, drought-based explanation of late sixteenth-century regional turmoil. ${ }^{95}$

Indeed, it seems best to regard synchronized late sixteenth-century upheavals as evidence not of economic difficulty, but of an excessive, ill-controlled vitality issuing from the above combination of rising maritime trade, firearms, agrarian expansion, state initiatives, and so forth. These forces fed a competitive process of consolidation all across the Indic mainland. Pegu simply proved itself the most successful player, and its stunning triumphs-first over the entire western mainland, then over Siam and most of the Tai world, including Laos-explain all instances of political collapse outside Dai Viet between 1555 and $1590 .{ }^{96}$ Likewise, its string of victories notwithstanding, Pegu's fissiparous imperial structure reflected a weakness common to all Indic polities. That is to say, the same inability to prevent outlying dependencies from defecting to the enemy as crippled Ayudhya and other kingdoms in the face of Peguan assaults undermined Pegu itself once Ayudhya counter-attacked in the 1590 . Thus, uncontrolled ambition and woefully inadequate territorial controls brought all the Indic mainland to grief in a few short decades.

If Dai Viet's remote position shielded it from Peguan attack, Dai Viet too fell victim to its own success. Renewed population pressure in northern Vietnam, rapid expansion along the eastern corridor, and the absence of a unifying riverine artery best explain the civil wars which tore apart Dai Viet in the second half of the sixteenth century and which, in the seventeenth century, produced a sustained north-south split. ${ }^{97}$

To summarize our findings for circa $145^{0}-1610-D e s i c c a t i o n$ favoured coastal districts in the west and centre, but climate's contribution to economic and political vigour across the mainland seems to have been far weaker than during the Medieval Climate Anomaly. So too, climate's contribution to coordinated political collapse after circa $\mathbf{1 5 5 ^ { 0 }}$ was more limited than in the late charter era because: (a) climate in the sixteenth century oscillated less wildly, and

${ }^{95}$ On the other hand, improved climate in northern Vietnam may have helped to destabilize the heartland by creating new land shortages.

${ }^{96}$ For an analysis of Pegu's advantages and a litany of its victories, see Lieberman, Burmese Administrative Cycles, Chapter 1; and SP, I, 123-1 54, 242-277.

${ }^{97}$ Li, Nguyen Cochinchina, 18-36, 159-163; SP, I, 394-399. 
may have been less geographically uniform, than in the thirteenth to fifteenth centuries; (b) whereas the three main charter polities rarely fought one another, Pegu in 1555 inaugurated a phase of warfare that destabilized the entire Indic mainland.

\section{Climate and political stress in the high pre-colonial era, circa 1610-1820}

Between circa 1610 and 1820 the post-charter integrative processes that had began during the fifteenth century-territorial consolidation, administrative centralization, and cultural homogenization-not only revived, but accelerated markedly. Whereas in 1340 the mainland held about 23 genuinely independent polities, and in 1555 perhaps eight, by 1820 only three remained: Burma, Siam, and Vietnam. Within each empire integration drew strength from a constellation of forces, many already familiar, including rising maritime trade and Chinese immigration, Western-style firearms, wider monetization, continuing if uneven population growth, expanding literacy, new educational networks, and wartime inducements to administrative and fiscal reform. As a result, by 1820 Kon-baung Burma, Chakri Siam, and Nguyen Vietnam governed the largest, most stable, most effectively integrated realms in mainland history. Compared with previous polities, provincial and religious autonomy was substantially reduced, resource extraction grew more 'routinized', and provincial, even tributary populations identified more readily with the ethnic and religious norms of each capital region. ${ }^{98}$

Mainland climate fluctuated more from 1610 to 1820 than at any time since circa $145^{\circ}$. Yet ever more resilient economies, administrations, and cultures allowed the chief states to withstand climate stress with some success-greater certainly than in the late charter era. To repeat our central thesis, whereas climate was erratic or cyclic, economic and political growth remained substantially linear. Scholars have suggested that post-1610 droughts disrupted one or another mainland kingdom in three periods, namely the 1630 , circa $1640-1680$, and between $175^{6}$ and 1805 . Yet only in the third era is the evidence persuasive. And even this is open to debate. Consider each period in turn.

${ }^{98}$ See discussion at $S P, \mathrm{I}, 15^{8-209}, 3^{02-335}, 4^{19-454}$. 


\section{Drought and politics in the 1630 s}

If Figure 3 shows appreciably thicker than average tree-rings from $1620-165^{\circ}$, PDSI values in Figure 1 from $1610-1640$ and in Figure 2 from $1630-165^{\circ}$ were generally low. Moreover, European records refer to appalling droughts and drought-induced famines all around the Bay of Bengal from 1629 to 1635 , and perhaps to $1640 .{ }^{99}$ On the basis of Dutch accounts, D. G. E. Hall argued that the Burmese famine of 1630-1635 was 'one of the worst on record' and helped persuade the ruler, Tha-lun, to return his capital by 1635 from coastal Pegu to Ava deep in the interior, in which region it would remain until 1885 .

[T] he whole country was famine-stricken, people were dying of starvation and trade was at a standstill. This alone would suffice to explain the decision to abandon an expansionist policy and seek safety in retrenchment. ${ }^{100}$

By insulating Burma from maritime influences, the move upriverwhich Hall termed 'one of the cardinal events in Burmese history'101_ bred 'intransigence and xenophobia' that contributed mightily to Burma's loss of independence to the British. Burma thus stood in sharp contrast to Siam, whose capital near the coast favoured a far more cosmopolitan, ultimately successful response to the European challenge. ${ }^{102}$

Hall's imperialist instincts aside, both his emphasis on 1635 as a turning point and his focus on the drought seem misplaced. The royal commitment to Ava over Pegu almost certainly dated from 1597 or 1613 , not 1635 , and responded to a host of factors-Upper Burma's demographic superiority, the strategic advantage of an upriver over

${ }^{99}$ Grove and Chappell, El Niño, pp. 15, 22; Reid, Age of Commerce, p. 293; idem, 'Seventeenth-Century Crisis', p. 655; D. G. E. Hall, 'The Daghregister of Batavia and Dutch Trade with Burma in the Seventeenth Century', JBRS 29 (1939): 140144; idem, Burma (London: Hutchinson's University Library, 195o), p. 66. Exiguous Dutch records from Burma for 1636-1640 leave us uncertain whether the drought continued past 1635 , but Dutch records from Siam refer to 'chronically bad crops throughout the 163os'. George Vinal Smith, The Dutch in Seventeenth-Century Thailand (DeKalb, Illinois: Northern Illinois University Center for Southeast Asian Studies, 1977), p. 61 .

${ }_{100}$ See references to Hall in previous note.

${ }^{101}$ D. G. E. Hall, Early English Intercourse with Burma $1587-1743$ ( $2^{\text {nd }}$ edn, London: Frank Cass and Co., 1968), p. 11.

102 Ibid., pp. 1 1-1 2, and Hall, Burma, 66, following G. E. Harvey, A History of Burma from the Earliest Times to Io March 1824 (rpt., London: Frank Cass and Co., 1967), pp. 193, 248-249. 
a downriver capital, the abandonment of plans to re-invade Siamquite separate from monsoon failure. ${ }^{103}$ In any case, as contemporary Dutch accounts make clear, ${ }^{104}$ and as befit a dry zone, Upper Burma in 1635 suffered from famine at least as severe as at the coast, so it is difficult to see how moving upriver offered the slightest climatic advantage.

Why, then, after returning to Ava in 1635 did the Restored Toungoo Dynasty (1597-1752) pursue an ambitious programme of administrative reform that included the formation of new military (ahmu-dan) regiments, novel controls on provincial governors, fresh curbs on monastic autonomy, and unprecedented valley-wide tax inquests? Did such measures seek to compensate for the 1629-1635 famine? In truth, those reforms began in the 1610 s and continued to the late 1600 . This chronology, plus the fact that royal edicts focused on military and fiscal concerns without mentioning drought, suggest that the new dynasty sought most basically to overcome those structural weaknesses, in particular the excessive autonomy of quasi-royal provincial governors, that had destroyed its First Toungoo predecessor. ${ }^{105}$

Such a view is reinforced by remarkably similar reforms in Siam starting in the 1570 and continuing for the better part of a century. These measures addressed not short-term climate-induced shortages, but administrative deficiencies that had become painfully apparent during Burmese attacks on Ayudhya in the $15^{60 s}$. Much like their Burmese counterparts, Siamese reforms included a radical expansion in royal manpower, more effective provincial controls, and new fiscal procedures. As such, they testified to secular improvements in the state's extractive and organizational capacity. Both Burma and Siam remained solar polities, but each sun's gravitational pull increased markedly. ${ }^{106}$

${ }^{103}$ To be fair to Hall, he too indentified some of these other factors. See Victor Lieberman, 'The Transfer of the Burmese Capital from Pegu to Ava',Journal of the Royal Asiatic Society of Great Britain and Ireland (1980): 64-83; idem, Burmese Administrative Cycles, 57-60.

${ }^{104}$ Hall, 'Daghregister of Batavia', p. 141; Wil O. Dijk, Seventeenth-Century Burma and the Dutch East India Company I634- I 680 (Singapore: Singapore University Press, 2006), pp. 82-83.

${ }^{105}$ Lieberman, Burmese Administrative Cycles, $65^{-11} 3,285^{-292}$; SP, I, $15^{8-164}$.

106 SP, I, 277-282 and Chapters 2, 3 passim. 


\section{Drought and politics in the mid and late seventeenth Century}

If we conclude from all this that in the 1630 s drought in parts of the mainland was real but political strains were muted, the situation may be distinguished from that later in the century. Between 1640 and 1680 both elements — drought and political upheaval—seem to have been modest, if not entirely absent.

This complicates Anthony Reid's aforementioned effort to assimilate Southeast Asia to a seventeenth-century Eurasian crisis rooted partly in Little Ice Age deterioration. In the mid and late 1600 , he argued, the same hemispheric cooling as impaired north European agriculture brought recurrent drought and famine to Southeast Asia. By eroding the local tax base and weakening indigenous merchants, such pressures joined Dutch aggression and falling export prices to rupture political and economic structures across the region. ${ }^{107}$

Although the islands lie beyond the scope of this paper, for that region Reid's thesis remains plausible. If we accept H. P. Berlage's teak tree-ring series from Java, recurrent droughts between circa 1640 and 1680 probably helped to weaken Makasar, Banten, and Mataram in their contests with the Dutch, and thus may have contributed to a genuine watershed in archipelagic development. ${ }^{108}$

On the mainland, however, the story seems quite different. PDSI readings show that between circa 1640 and 1685 southern Vietnam became appreciably wetter, not drier (Figure 1). Data from northern Vietnam (Figure 2) also point to improved monsoons between circa $165^{\circ}$ and 1670 , whilst tree-rings from northwest Thailand (Figure 3) show that rainfall was average from circa $1640-1660$ and well above average from circa $1670-1685$. These findings, much at variance with Berlage, must be weighed against the low PDSI ratings between 1670 and 1690 shown in Figure 2, against Dutch reports from Siam of droughts in 1645 , 'periodically in the $1655^{\circ}$ ', and in $1675,{ }^{109}$ and against unusually low 'wetness index' readings for Guangzhou in South China from $165^{0-1} 700 .{ }^{110}$ And yet, all things considered, the image of markedly unfavourable climate in the mid and late seventeenth

107 See n. 1 supra.

108 See n. 4 (with Berlage data) supra plus SP, II, $841-844,858-868$.

109 Dhiravat na Pombejra, 'A Political History of Siam under the Prasatthong Dynasty 1629-1688' (University of London Ph.D. Dissertation 1984), pp. 225, 334; Smith, Dutch in Seventeenth-Century Thailand, p. 61.

110 Marks, Tigers, Rice, pp. 199-200. 
century, an image promoted by Lieberman as well as by Reid without benefit of mainland dendrochronology, seems overdrawn. ${ }^{111}$

Assuming subsequent research confirms this conclusion, how should we treat the evidence of political breakdown on the mainland that Reid marshalled to substantiate his seventeenth-century crisis theory? In Burma, Reid is correct that administration came under pressure between 1664 and 1698 as royal servicemen (ahmu-dans) sought to avoid their obligations by illegally mortgaging royal lands and becoming debt-slaves to princes and leading officials. In some years high rice prices, hence popular distress, may have been linked to poor rainfall. ${ }^{12}$ Yet the aforementioned structural reforms ensured that seventeenth-century disorders never rose to the level of a generalized crisis. Until the 1720 , or indeed the 1730 s, the service system continued to function more or less adequately, the court survived endemic factionalism, and the outer zones of empire remained reasonably secure.

Nor is evidence of political/economic retrenchment in seventeenthcentury Siam or Vietnam at all compelling. If upheavals attending the so-called Revolution of 1688 at Ayudhya reduced European influence, to speak of a post-1688 Siamese retreat from international commerce is quite misleading insofar as Chinese trade more than compensated for European withdrawal. In any case, the Revolution of 1688 had no obvious link to climate. Between circa 1640 and 1740 continued reclamation in the Chaophraya basin, proliferating rural markets, rising land values, and new commercial taxes all point, as in Burma, to a more productive, diversified, and monetized rural economy. ${ }^{113}$ Likewise in Vietnam, warfare between the northern Trinh and the southern Nguyen regimes from 1627-1672 should be seen as a sign not of economic or political crisis in the manner of island Southeast Asia, rather of southern vitality as manifest in continuous frontier migration, the displacement/encapsulation of ethnic minorities, the spread of cash cropping, and burgeoning maritime trade. Also, in the more densely populated Trinh domain between circa 1630 and 169o, agrarian and commercial specialization, New World crops, and

${ }^{111}$ See Lieberman's comments at SP, I, 174, 295, and 295 n. 254.

112 Lieberman, Burmese Administrative Cycles, pp. 152-181, especially 176-177.

113 SP, 288-302; Victor Lieberman, 'An Age of Commerce in Southeast Asia? Problems of Regional Coherence', JAS 54 (1995): 796-8o7. Cf. Reid, Age of Commerce, pp. 3o6-309. 
generally adequate rainfall led to a growth in its population of around 17 per cent. ${ }^{114}$

Climate, economics, and politics in the eighteenth and early nineteenth centuries

On balance, then, both Reid and Lieberman seem to have painted an excessively bleak picture of seventeenth-century climate. Relying on European and indigenous records but again without tree-ring studies, Lieberman erred in the opposite direction for the eighteenth century, most of which he characterized as climatically benign. ${ }^{115}$

Now it is true that southern Vietnamese PDSI readings in Figure 1 were elevated between 1720 and circa 1745 , with those for $1730-173^{2}$ being the highest since the thirteenth century. Likewise, in Figure 2 from northern Vietnam, most years from 1715 to 1745 and from 1770 to 1815 saw above-average readings; whilst Thai tree-wing widths in Figure 3 also tended to be above average during the years $1720-1738$ and $1770-1815$.

However, in much of mainland Southeast Asia and adjacent regions these good years were both bracketed and bisected by very poor weather indeed. At one end, the late 1600 - - which Richard Grove and John Chappell label a 'mega-[El] Niño' era-and the early 1700 s saw droughts and drought-related famines and epidemics in Burma, Siam, Laos, South China, and much of India. ${ }^{116}$ Continuing in some locales to 1716 , these shifts show clearly in Figures 1 and 3 (though curiously not in Figure 2). The late eighteenth century also saw repeated monsoon failures. Grove and Chappell term these latter events a second 'mega-[El] Niño', while Edward Cook and co-authors of the recently published Monsoon Asia Drought Atlas (MADA) refer to the failures of 1790 and $1792-1796$, which produced extremely high

114 SP, I, 399-420; Li, Nguyen Cochinchina, with population figures on pp. 159-16o.

115 SP, I, 1 74, 294, 299, 402, 438-439; SP II, 459.

${ }^{116}$ Grove and Chappell, El Niño, pp. 16, 19-20; U Kala, Maha-ya-zawin-gyi, III, 333, 337, 379; Lieberman, Burmese Administrative Cycles, pp. 176-177; Dhiravat na Pombejra, 'Ayutthaya at the End of the Seventeenth Century', in Anthony Reid, ed., Southeast Asia in the Early Modern Era (Ithaca: Cornell University Press, 1993), p. 257; idem, 'Princes, Pretenders, and the Chinese Phrakhlang', in Leonard Blusse and Femme Gaastra, eds, On the Eighteenth Century as a Category of Asian History (Aldershot, United Kingdom: Ashgate, 1998), p. 116; Stuart-Fox, Lao Kingdom, p. 95; Marks, Tigers, Rice, p. 200; SP, I, 295, 295 n. 254. 
mortality rates in India, as the 'East India Drought'. ${ }^{117}$ Apparently related to that event were monsoon failures in Burma from 18021812 that the Burmese dubbed the 'maha-thayaw', the 'great debris', from the fact that corpses were left strewn across the landscape like debris (thayaw). ${ }^{118}$ Finally, roughly midway between droughts at either end of the eighteenth century occurred what Cook and his co-authors term the 'Strange Parallels Drought', which they date to $175^{6-1} 768$ but which, Figures 1, 2 and 3 suggest, may already have been under way by the late $174 \mathrm{Os}$. "This spatially broad and persistent "megadrought" from India to Southeast Asia is one of the most important periods of monsoon failure found in the MADA ${ }^{\prime 19}$ and appears prominently in all three of our dendrochronological reconstructions. ${ }^{120}$ According to Figure 1, weak monsoons continued, with only brief interruptions,

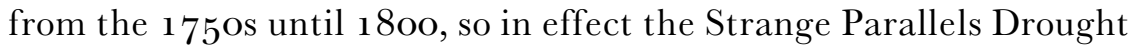
merged with those at the end of the century.

What was the political impact of these newly discovered patterns? The same data can support conflicting interpretations.

One could argue that the Strange Parallels and East India Droughts contributed to late eighteenth-century breakdowns across the mainland, including the collapse of Ayudhya in 1767 , of Nguyen Vietnam from 1771-1785, and of Trinh Vietnam in 1786. In fact, Cook and his colleagues were quick to note that the Strange Parallels Drought 'coincided with a time of substantial societal upheaval and political reorganization across Southeast Asia', whilst the East India Drought 'was felt worldwide and resulted in widespread civil unrest and socio-economic turmoil'. ${ }^{121}$

At Ayudhya, five dynamics prepared the way for the 1767 debacle at the hands of Burmese invaders: (1) excessive demands led many royal servicemen (phrai luang) to evade military and corvee commitments to the throne in order to join the private retinues of princes and

117 Grove and Chappell, El Niño, 17-22; Cook, 'Asian Monsoon Failure'. See also Richard Grove, 'The Great El Niño of $1789-93$ and Its Global Consequences', The Medieval History Journal 10 (2007): 75-98; Marks, Tigers, Rice, 200, Figure 6.3. These droughts also register in Figure 1, but (for reasons by no means clear) not in Figures 2 and 3 .

${ }_{118}$ William Koenig, The Burmese Polity, I752-I8I9 (Ann Arbor: University of Michigan Center for South and Southeast Asian Studies, 1990), pp. 33-36, 53, 59 .

119 Cook, 'Asian Monson Failure', p. 487. See too Sinha, 'A Global Context for Megadroughts'.

${ }^{120}$ However, these droughts do not figure prominently in Guangzhou data. Marks, Tigers, Rice, p. 200, Figure 6.3.

${ }^{121}$ Cook, 'Asian Monson Failure', p. 487; also Grove, 'Great El Niño'. 
high officials; (2) wider money-use increased debt-slavery amongst hard-pressed servicemen, again to the benefit of private patrons; (3) a rising population meant that the number of applicants for official posts outpaced available openings, which intensified court factionalism; (4) by disrupting the agrarian-based status hierarchy, commercialization also stoked intra-elite tensions, whilst encouraging downwardly mobile elites to step up their compensatory recruitment of private manpower; (5) succession disputes led to actual or threatened military conflict in the capital, which further impeded a coordinated response to the Burmese. Scholars have yet to analyze the intersection of climate with these patterns, but it is reasonable to assume that by impoverishing commoners, accelerating the flow of phrai luang from royal to private service, depressing the income of some sectors of the elite, and intensifying intra-elite competition, the Strange Parallels Drought magnified, powerfully perhaps, all five problems. ${ }^{122}$

The Vietnamese lowlands present a comparable picture. The Tayson revolt that overthrew first the Nguyen and then the Trinh regimes grew from at least three tensions: (1) in north and central Vietnam eighteenth-century population growth reintroduced land shortages and fiscal pressures characteristic of the late fourteenth and sixteenth centuries; (2) lacking adequate supplies of specie, the overheated South China Sea economy sucked money out of Vietnam to supply South China and thus played havoc with Vietnamese taxation; (3) battling Siam to control the Mekong delta, the Nguyen became territorially and fiscally over-extended and sought to compensate with insupportable tax demands on the Qui Nhon region and on nearby hillpeople. Recurrent drought can only have magnified all three problems, along with popular discontent. The Taysons arose in Qui Nhon in 1771 , shortly after Cook's Strange Parallels Drought, and took power in 1785 , in part by exploiting hatred of Nguyen taxes. Figure 1, derived from trees close to Qui Nhon, shows severe desiccation in the latter half of the eighteenth century. ${ }^{123}$

In sum, evidence suggests that adverse climate helped to catalyze some eighteenth-century upheavals. In this view, the late 1700 s

122 SP, I, 299-302; Wyatt, Thailand, Chapter 5; Akin Rabibhadana, The Organization of Thai Society in the Early Bangkok Period, $1782-1873$ (Ithaca: Cornell University Southeast Asia Program, 1969), Chapter 2.

${ }^{123}$ On Vietnamese history and famines 1771-1802, George Dutton, The Tay Son Uprising (Honolulu: University of Hawaii Press, 2006), especially Chapter 1, pp. 2636, 43-56, 46, 79, 87, 99-100, 164, 212 ; Li, Nguyen Cochinchina, Chapter 7; SP, I, 419-427. On climate, see too Marks, Tigers, Rice, p. 200, Figure 6.3. 
offered a compressed replay of events between $125^{\circ}$ and $145^{\circ}$. In each case, institutional weaknesses joined economic growth-the latter spurred in some degree by periods of favourable pluviation-to create political fissures that monsoon failure suddenly burst wide open.

However, one can also find plenty of evidence for the marginality of climate after 1700. After all, to take the example of Siam, monsoons in the late 1600 s and early 1700 sere quite anaemic, but had no discernible political impact, no doubt because those social and institutional strains characteristic of the mid 1700 s had yet to mature. ${ }^{124}$ Likewise, because the Chakri Dynasty which took power in Siam in 1782 pursued extensive reforms, it not only proved immune to the East India Drought of the 179os, but in those very years strengthened its strategic position in all directions and reached military parity with Burma, which itself was in a phase of aggressive expansion. Self-consciously determined to remedy Ayudhyan weaknesses and benefiting from European guns, from rapidly expanding Chinese trade and immigration, and from pervasive commodification, the Chakri court introduced new systems of manpower control, commuted labour services, expanded wage labour, and created trade monopolies whose benefits were widely shared amongst the elite. State resilience in the face of climatic adversity also reflected long-term cultural dynamics-rising literacy, the growth of vernacular literature, the vertical and horizontal dissemination of Theravada norms together with a pronounced sense of Siamese ethnic loyalty - all of which served to enhance popular identification with the capital. ${ }^{125}$

Burma's fortunes, one could argue, showed yet more clearly climate's marginality. On the one hand, when the Restored Toungoo

${ }^{124}$ Thus, consistent with our Figures 1 and 3, the account, first published in 1771 , by F. H. Turpin, History of the Kingdom of Siam and of the Revolutions That Have Caused the Overthrow of the Empire Up to A.D. I 770 , B. O. Cartwright, tr. (Bangkok: American Presbyterian Mission Press, 1908), 111-114, 126-168 passim offers evidence of drought and famine at the start of the eighteenth century far more severe than any deficiencies circa $175^{\circ}-1770$.

${ }^{125}$ SP, I, 302-335; Wyatt, Thailand, Chapter 6; Hong Lysa, Thailand in the Nineteenth Century (Singapore: Institute of Southeast Asian Studies, 1984). In theory perhaps, it could be argued that the Strange Parallels Drought weakened all mainland actors, so that Siam grew stronger not in absolute terms, merely in relation to Burma and Vietnam. But in fact, by all fiscal, military, organizational, and cultural criteria, Siam in 1800 was far more cohesive and efficient than its Ayudhyan predecessor. A similar progression characterized Burma and Vietnam between $175^{\circ}$ and 1820 , so that in effect the bar for all mainland actors was constantly being raised. SP, I, Chapters 2-4. 
state fragmented around 1740 , it did so not in a period of diminished rainfall—as Ayudhya would do in 1767-but with fully adequate monsoons. In Figures 1, 2, and 3 rainfall from circa 1720-1740 tended to be above average. Yet in those very years Burma fell prey to problems similar to those that would undermine Ayudhya. Ahmu-dans fled royal service for private service. Commercial and demographic growth fed elite factionalism at the same time as it led impoverished servicemen to become debt-slaves. Private retinues undermined military coordination. By 1740 the state was teetering. ${ }^{126}$ Thus the Burmese and Siamese states faltered in comparable ways, but according to very different climatic schedules. How critical an agent of destabilization could climate therefore have been?

On the other hand, Burmese political structures proved unusually resistant to drought when it did occur, at least compared to the late charter era. Neither during the 1630s drought, the 1690-1716 mega-El Niño, the Strange Parallels Drought of $175^{6-1768 \text {, nor }}$ the East India Drought and associated maha-thayaw of circa 17901812 did the Burmese state-as opposed to the populace-suffer in any demonstrable way. Indeed, with the partial exception of the 1690 , each of these periods saw convincing displays of dynastic vigour. Thus, as already noted, Restored Toungoo officials pursued foundational reforms in the 1630 , whilst the Kon-baung Dynasty $\left(175^{2-1885}\right)$ achieved its greatest military triumphs between $175^{6}$ and 1768 and launched attacks against Manipur and Siam at the height of the maha-thayaw. Like its Chakri contemporary, the early Kon-baung state strengthened manpower control, monastic supervision, military mobilization, and taxation. It too benefited from monetization, agrarian diversification, market integration, and from an ever more inclusive, emotionally charged, proto-national ethnic loyalty. The latter drew on mass monastic education, denser market circuits, and the galvanizing legacy of Burman-Mon and BurmanSiamese warfare. In both Burma and Siam growing cultural-cumadministrative cohesion helps explain why the eighteenth-century interregnum was shorter and less disruptive than that of the late 15 oos-early 1600 , which in turn was far more abbreviated than postcharter collapse. ${ }^{127}$

Nor in the eastern lowlands after the early Tayson success does climate seem to have played a major role. According to Figures 1

${ }^{126}$ SP, I, 1 82-1 83; Lieberman, Burmese Administrative Cycles, Chapter 3.

127 SP, I, 164-209; Koenig, Burmese Polity, Chapter 1. 
and 2, rainfall in southern Vietnam in the late 1780 os and 1790 s was markedly less favourable than in the north. Yet the Nguyen insurgency that overthrew the Tayson in 1802 was based in the south, which benefited from multifaceted agrarian and commercial expansion and from innovative marine military technologies, while it was in the centre and the north of Vietnam that the Tayson held out. ${ }^{128}$

According to this more restrictive view of climate, coordinated political collapse across the mainland in the latter 1 7oos reflected climate less than what might be termed a 'military domino effect'. This pattern resembled that of the late sixteenth century, yet was more geographically inclusive. Having disintegrated in the 1740s, the Burmese state-benefiting from resilient local cultural and social networks-revived in the $175^{\text {os }}$ with such panache that it was able to destroy Ayudhya in 1767 . Recovering quickly from the Burmese invasion and likewise drawing upon persistent capillary-level systems, Siam challenged the Nguyen in Cambodia in 1770-1 771 . This threat helped to precipitate the Tayson revolt of 1771 , which led to the fall of the Nguyen and the Trinh and to eventual unification under the unprecedentedly powerful, restored Nguyen Dynasty. ${ }^{129}$ Thus movements of political collapse and revival spread like a shock wave all the way from the mainland's western to eastern frontiers.

Note that if charter florescence and fourteenth/fifteenth century disintegration found echoes outside Southeast Asia, this early modern pattern of accelerating, sustained administrative and cultural integration also fits wider Eurasian trends. ${ }^{130}$

\section{Conclusion}

Because paleoclimatology in mainland Southeast Asia is still at an early stage, this paper seeks to stimulate historical interest more than to provide definitive answers. We consider only monsoon effects, to the neglect of temperature and other potentially influential variables. Our monsoon proxy data are limited geographically and temporally, and such data as we have are not always consistent.

${ }^{128}$ See n. 123 supra; SP, I, 419-454; and Nola Cooke and Li Tana, eds, Water Frontier: Commerce and the Chinese in the Lower Mekong Region, I750-I880 (Singapore: Singapore University Press, 2004); Dutton, Tay Son Uprising.

${ }^{129} S P, \mathrm{I}, 422-423$.

130 See discussion in SP, II, Chapters 2-6. 
Nonetheless, as a provisional thesis, we have argued that from the charter era to the early nineteenth century rainfall levels had a major, but decreasing, political and economic impact. Indeed, the eras circa $95^{0}-125^{\circ}$, circa $125^{\mathrm{O}-1} 45^{\mathrm{O}}$, circa $145^{\mathrm{O}-1610}$, and circa $1610-1820$ formed something of a logical progression.

During the first two periods climate provided a spur, by no means exclusive but in some cases apparently pivotal, to the more or less synchronized florescence of charter civilizations-and to synchronized charter collapse. Climate's coordinating power in these centuries reflected the unusual amplitude of Medieval Climate Anomaly and early Little Ice Age monsoon variation, plus the fact that political decentralization, cultural heterogeneity, and relatively undifferentiated economies left charter states particularly vulnerable to climatic disruption. Directly and indirectly, Tai incursions and maritime trade-two other precipitants of charter collapse-also benefited from high Medieval Climate Anomaly pluviation. At the same time the relative isolation of the charter states from one another precluded the sort of military coordination across the mainland found in later centuries.

Although between circa $145^{\circ}$ and 1610 climate continued to influence political rhythms, its synchronizing impact diminished for three reasons: (1) on present evidence, monsoon oscillations across the mainland were more restrained than in earlier centuries; (2) climate in northern Vietnam seems to have been moderately distinct from that elsewhere in the mainland; (3) for the first time interstate warfare provided a major agency of synchronization in the west and in the centre.

Finally, between circa 1610 and 1820 rainfall fluctuated more widely than at any time since 1300. But whilst the exact political impact, especially in the eighteenth century, is open to interpretation, on balance climate's ability to coordinate development across the mainland seems to have been limited by the growing, multifaceted solidity of each realm and by an associated increase in interstate warfare. In each empire, integration drew on secular increases in population and in agrarian, commercial, and cultural capital. All such factors benefited from periods of adequate rainfall after 1610 , but few can be reduced to an epiphenomenal artefact of climate. 